\title{
Hydrogeologic Assessment of the 4-S Land and Cattle Company Ranch
}

\author{
Prepared for: US Bureau of Reclamation
}

\author{
Nigel W.T. Quinn \\ Berkeley National Laboratory \\ 1 Cyclotron Road, Bld,. 70A-3317H \\ Berkeley, CA 94720
}

April 10, 2006

This work was supported by the U.S. Bureau of Reclamation under US Department of Interior Interagency Agreement No. 3-AA-20-10970 through U.S. Department of Energy Contract No. DE-AC03-76SF00098 


\section{ACKNOWLEDGEMENTS}

This report was prepared for the US Bureau of Reclamation to assist the agency make planning decisions with respect to potential acquisition of additional lands to secure water supply to Grasslands Basin wetlands. The author gratefully acknowledges the financial support provided by Dan Meier, MP410 who also set the project in motion by arranging initial contacts with the Ranch Foreman, Mr August Oertzen. Mr Oertzen's knowledge of the Ranch and willingness to participate in the project was material to the project's success and was much appreciated. Dr Grace Su and Paul Cook of Berkeley Bational Laboratory assisted with the field monitoring and both individuals contributed to the development of improved water quality logging technology, the write-up of which has been accepted for publication in the technical journal Groundwater. Dr Chin-Fu Tsang and Dr Chris Doughty, also of Berkeley National Laboratory provided early assistance as we were learning the theoretical basis of the well logging technique, which we subsequently adapted to our needs. Dr Kenneth Schmidt provided invaluable access to reports and data, as well as advice, based on his many years of groundwater quality consulting in the San Joaquin Valley. Will Shipp, now in Reclamation Headquarters in Washington DC, provided financial support for the technology development aspect of the project and has been a strong advocate of the use of advanced geophysical monitoring techniques within Reclamation.

I also would like to thank the following for their helpful review comments including Will Shipp, Dan Meier and Michael Heaton with the US Bureau of Reclamation; Dr Kenneth Schmidt of Kenneth D. Schmidt and Associates; and both Dr Terry Hazen and Dr Grace Su at Berkeley National Laboratory. 


\section{TABLE OF CONTENTS}

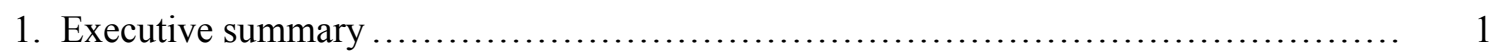

2. Hydrogeological assessment

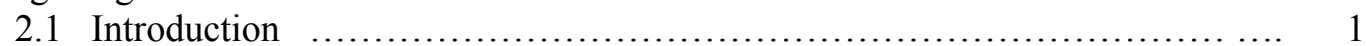

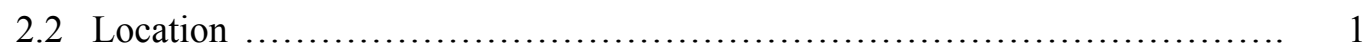

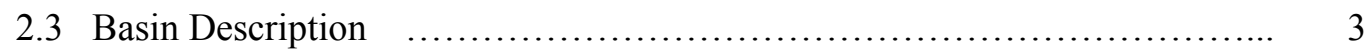

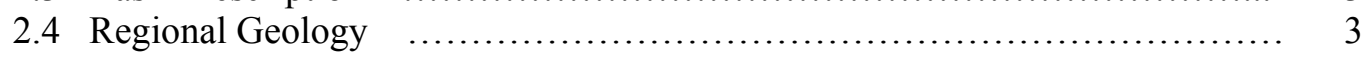

2.5 Local Hydrogeology ................................................ 5

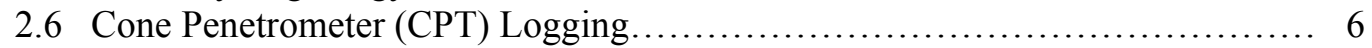



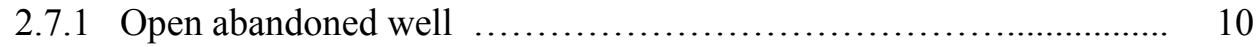

2.7.2 Ambient EC profiles......................................... 10

2.8 Subregional Groundwater Quality....................................... 15

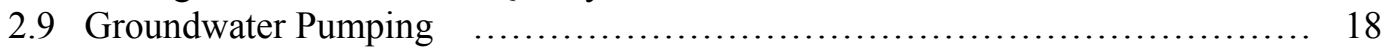

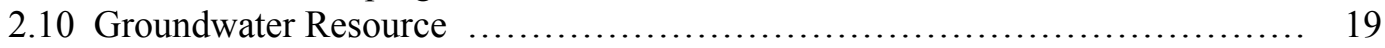

2.11 Groundwater Levels and Aquifer Safe Yield.............................. 19

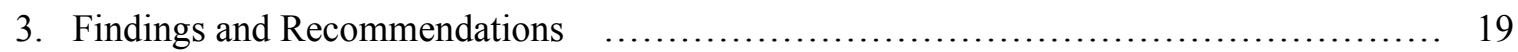

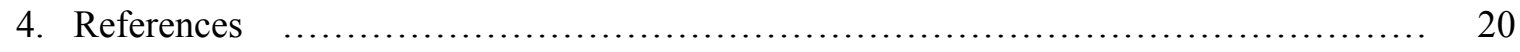




\section{EXECUTIVE SUMMARY}

Hydrogeological assessment of the 4-S Land and Cattle Company (4-S Ranch) was conducted using a combination of field investigations and a survey of available literature from nearby agricultural water districts and other entities. The 4-S Ranch has been able to meet most of its own water needs providing irrigated pasture for beef cattle by an active program of shallow groundwater pumping in the semiconfined aquifer above the Corcoran Clay. Comparison of groundwater pumping on the 4-S Ranch property with groundwater pumping in the adjacent Merquin and Stevinson Water Districts shows great similarity in the well screened depths and the quality of the groundwater produced by the well fields. The pump yield for the eight active production wells on the 4-S property are comparable to the production and drainage wells in the adjacent water districts. Like these Districts the 4-S Ranch lies close to the Valley trough in a historic discharge area. The 4-S Ranch is unique in that it is bounded and bisected by several major water conveyance facilities including Bear Creek. Although the large number of potential recharge structures would suggest significant groundwater conjunctive use potential - the major well field development has occurred along the length of the Eastside Canal. The Eastside Canal is known to be leaky above the "A" Clay - the Canal passes through sandy areas and experiences significant groundwater seepage. This seepage can be intercepted by adjacent groundwater wells. Pumping adjacent to, and along the alignment of the Canal, may induce higher rates of seepage from the Eastside Canal. Groundwater quality below and adjacent to the Eastside Canal is very good, reflecting the origin of this diverted water from the Merced River. Most of the pumpage occurs in a depth interval between $30 \mathrm{ft}$ and 130ft. Safe yield estimates made using the available data show that the 4-S Ranch has sufficient resources to meet its own needs. Further exploitation of the groundwater will be limited if the leakage from the Eastside Bypass, Mariposa Bypass and Bear Creek are insufficient to replace the pumped water on an average annual basis. Should any future lining of the Eastside Canal occur, it would have a significant impact on the groundwater resource potential of the 4-S Ranch and impair the overall quality of the available water supply.

\section{HYDROGEOLOGICAL ASSESSMENT}

\subsection{Introduction}

The goal of this hydrogeological report is to provide an assessment of the groundwater resource conditions below the 4-S Ranch in western Merced County. The US Department of Interior is considering the purchase of the property from the landowner for the purpose of meeting wildlife habitat needs. One of the potential assets of the property would be the groundwater supply that could be used for on-site management of the property as a wildlife refuge and/or the export of this groundwater to be used on managed wetlands in the vicinity of the 4-S Ranch.

\subsection{Location}

The 5,401 acre 4-S Ranch property is located within western Merced County approximately 6 miles due east of the intersection of Highway 165 and Highway 140 (Figure 1). The property is bounded by the Eastside Canal on its northern boundary, follows the boundary between section 2 and 3 of Township T8SR11E due south for a little over 5 miles on its western boundary including a section of the Mariposa Bypass. Two miles of the levee that runs along the southern bank of the Mariposa Bypass forms the southern boundary of the property. The eastern boundary of the property follows the boundary of sections 13 and 18 in adjacent townships starting at the north-east corner of section 13 in township T8S-R11E but jogs to the east one mile south of this intersection along Green House Road for 1/3 mile to enclose a 2/3 mile long reach of Owens Creek downstream of the Green House Road bridge. The west bank of the Eastside Canal forms a 3/4 mile boundary for the property to the intersection of Owens Creek and the Eastside Canal, which is the most easterly point of the property. South of this point the property 


\section{ASSESSOR'S PARCEL MAP}

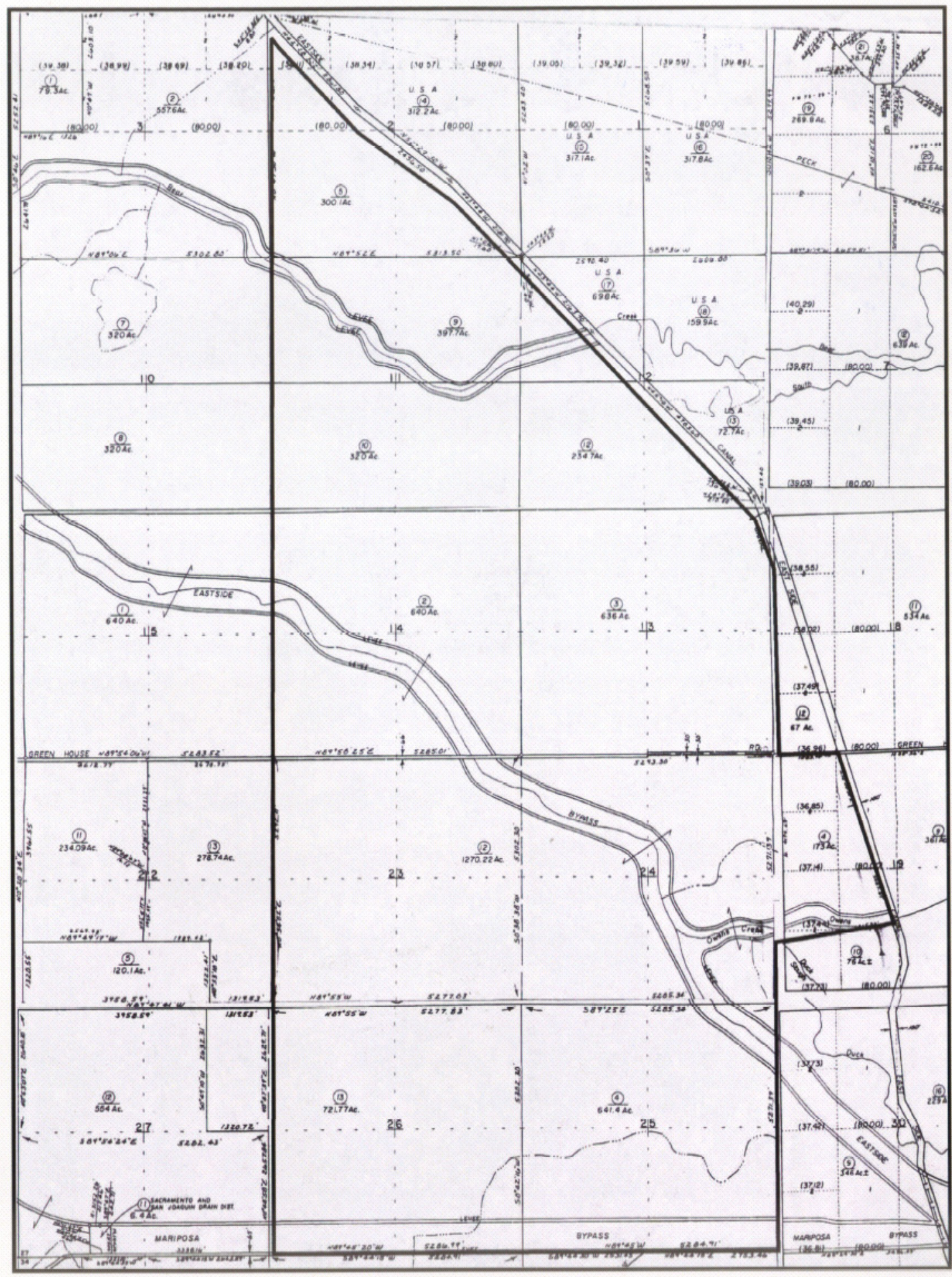

Figure 1. Map of the boundary of the 4-S Ranch in Merced County - Township R12E T8S. 
boundary jogs back to the original property line bisecting sections 19 and 24, 25 and 30 in adjacent townships to the south bank of the Mariposa Bypass.

Bear Creek and the Eastside Bypass run through the property. Approximately 1.5 miles of Bear Creek run through the north western corner of the property and a little over 3 miles of the Eastside Bypass runs through the center and south-eastern quadrant of the property. It is apparent from the configuration of the property that the landowners have attempted to maximize the availability of stream-aquifer recharge from large water conveyance facilities along three of the four property boundaries. These surface water conveyances typically carry high quality water from sources in the Sierra Nevada Mountain range. The proximity to the Eastside Canal also provides the landowner with easy access for direct diversions from the Eastside Canal or Bear Creek should the need arise and if contractually permissible. It appears that the landowners have sought to maximize use of the groundwater resource potential of the property, given the recharge potential from the surface water conveyance facilities on three sides of the property.

\subsection{Basin description}

The 4-S Ranch lies within the Merced Groundwater Basin within western Merced County almost due west of the City of Merced and to the east of the San Joaquin River. Figure 2 shows the geographic extent of the Merced Groundwater Basin. The Merced Groundwater Basin is bounded by the Merced River on the north, the San Joaquin River to the west and the Chowchilla River on the south and contains over a great number of municipal, industrial, agricultural and domestic wells (Schmidt, 2005). Wells in the groundwater basin have been reported as having capacities ranging from 100 to 4,500 gallons per minute (DWR, 2003). The existing well field within the 4-S Ranch was most likely developed in the 1960 's or early 1970's - these wells have capacities ranging from 434 to 1,946 gallons per minute.

\subsection{Regional geology}

The San Joaquin River Basin is a large structural trough filled with approximately 16,000 feet of eroded sediments from the granitic Sierra Nevada and the marine shales and siltstones of the Coast Range. These sediments derived from alluvial fans, rivers and shallow lakes that formed complex layered beds of various geologic materials that were later folded by landforming stresses in the earth's mantle. A generalized regional San Joaquin Valley cross-section is provided in Figure 3, derived from an hydrogeological assessment report by Bookman-Edmonston (2003) for the Stevinson and Merquin Water Districts. This report shows that only the upper $400-800 \mathrm{ft}$ of the sedimentary material contains groundwater suitable for agricultural, domestic and industrial use and for managed wetlands. The regional geology of the groundwater system beneath the 4-S Ranch is largely derived from this report and by a more recent report by Ken Schmidt and Associates (Schmidt, 2005). An earlier US Geological Survey report by Gary Balding and Ron Page (USGS, 1971) of aquifer and well water quality data within the Modesto and Merced area provides some of the background geology upon which these later reports are based.

The upper 1,500 $\mathrm{ft}$ of sediments is comprised of both young and old alluvium, continental deposits and the Mehrten Formation (USGS, 1973). The Younger Alluvium consists of narrow bands of fine sand, sand and gravel with little or no hardpan and typically is found along river courses. This alluvial material ranges in thickness from $0-100$ feet (USGS, 1973). The Older Alluvium is the more pervasive exposed structural unit in the vicinity of the 4-S Ranch and below the Stevinson and Merquin Water Districts, located less than 5 miles to the north-west. This structural unit comprises interbedded sand, silt, clay and gravel with some hardpan at shallower depths, and ranges in thickness from 400 to $700 \mathrm{ft}$ below the land surface (Bookman-Edmonston, 2003). The bottom of the Older Alluvium is typically between $400 \mathrm{ft}$ and $600 \mathrm{ft}$ below sea level and is apparent in drillers logs as a transition from coarse grained to fine grained sediments (USGS, 1971, 1973). 


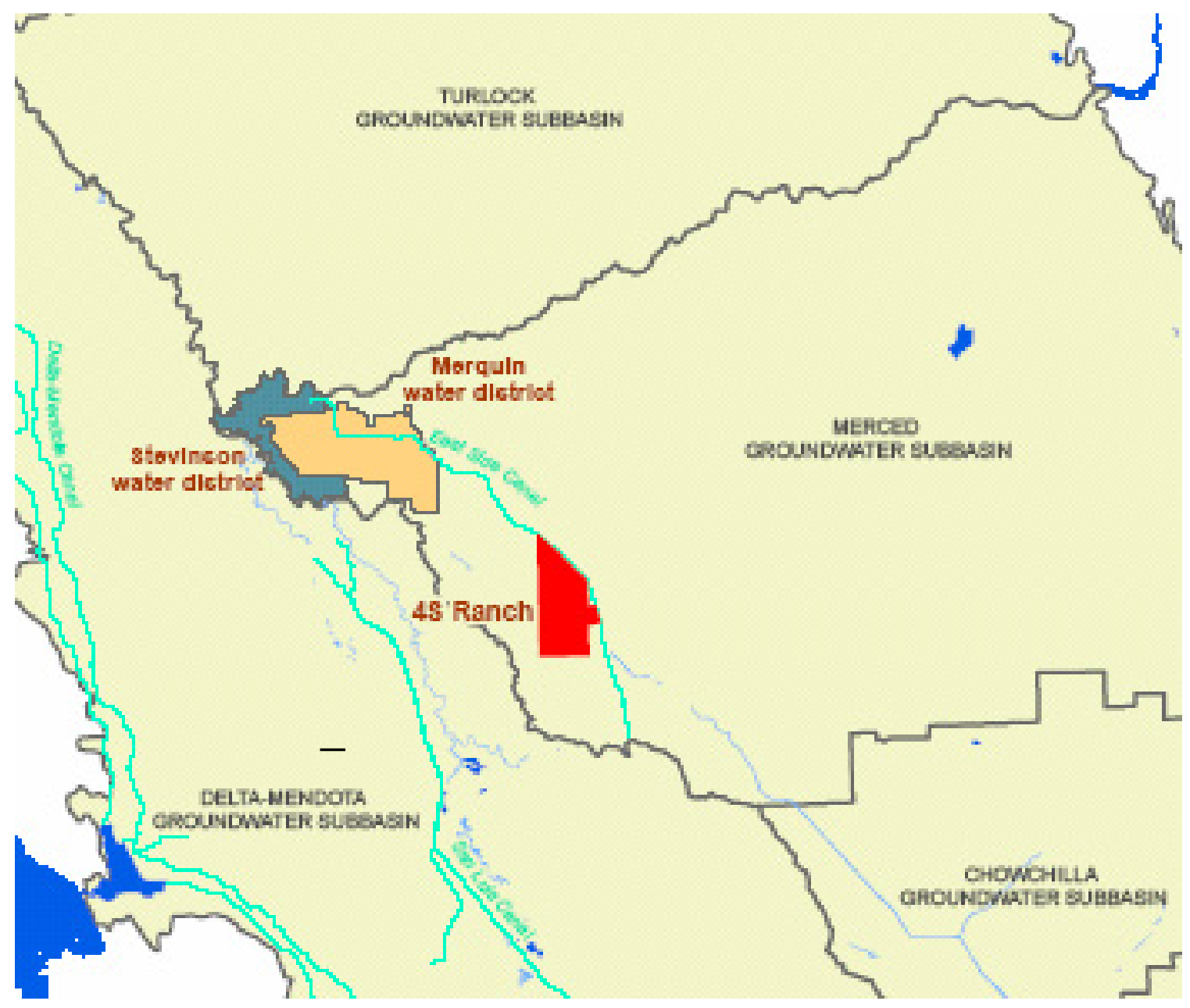

Figure 2. Merced Groundwater Basin showing location of Stevinson and Merquin Water Districts located north-west of the 4-S Ranch (Source : Bookman-Edmonston, 2003).

Embedded within the Older Alluvium are a number of continuous lacustrine deposits of gray and blue silts, silty clays and clays that display low permeability and act as impermeable barriers to vertical groundwater movement. The most significant of these deposits is the Corcoran "E" Clay which is regionally extensive in the Valley trough between Tracy and Kern County and which pinches out close to the alignment of Highway 99 in the eastern San Joaquin Valley, north of Chowchilla and in the vicinity of Highway I-5 in the western San Joaquin Valley. In western Merced County the Corcoran Clay extends to Merced and Atwater and hence underlies the extent of the 4-S ranch. The Corcoran Clay is at its thickest in the Valley trough reaching thicknesses of 80-100 ft (Bookman-Edmonston, 2003). It is approximately $60 \mathrm{ft}$ thick in the vicinity of the 4-S Ranch.

The Continental Deposits are to be found beneath the Older Alluvium - the base of the Deposits extend to between $400 \mathrm{ft}$ and $800 \mathrm{ft}$ below sea level (Bookman-Edmonston, 2003). Water quality in the upper sections of the Continental Deposits is acceptable for many uses with an average electrical conductivity (EC) below 3,000 umhos/cm. The "base" of this fresh water - typically defined as the interface between water with an EC below $3000 \mathrm{uS} / \mathrm{cm}$ and poorer quality water - is not well defined and has been mapped by the USGS to be approximately $500 \mathrm{ft}$ below mean sea level. Beneath the Continental Deposits lies the Mehrten Formation which is comprised of deposits of sandstone, tuff, siltstone, breccia, claystone and conglomerate often referred to by local drillers and "black sand and gravel" (Bookman-Edmonston, 2003; 
USGS, 1973). Although the depth of this formation is generally unknown because no wells have been sunk this deep, largely on account of abundant shallow water resources, it is an important aquifer in both the Sacramento and San Joaquin Valleys and has permitted well production between 1,500 and 3,500 gpm (Bookman-Edmonston, 2003).

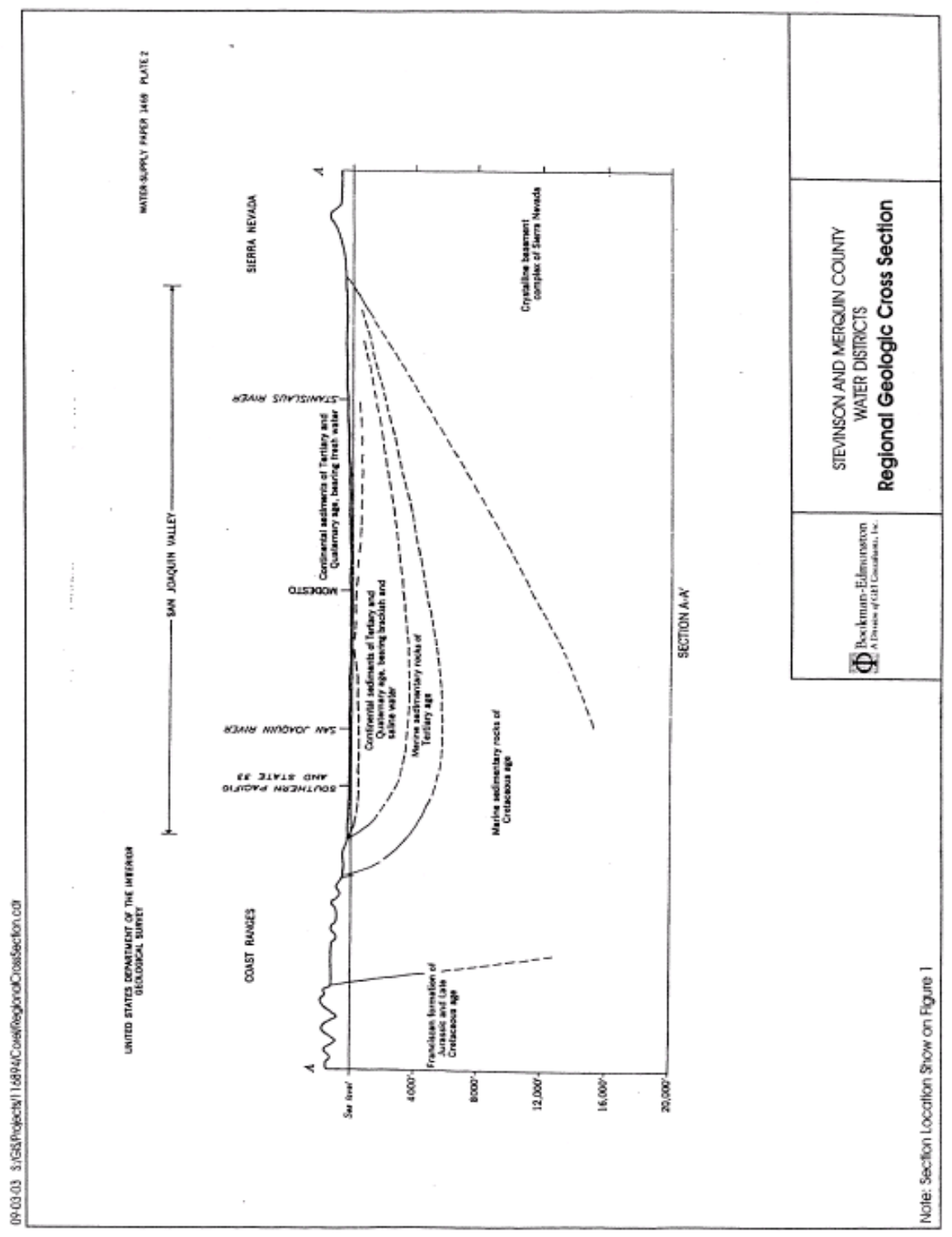

Figure 3. Generalized cross-section of the San Joaquin River Basin in proximity to the 4-S Ranch. (Source : Bookman-Edmonston, 2003).

\subsection{Local hydrogeology}

The local geology dictates the nature of the local groundwater system and can be derived from well driller's reports, geophysical logs, consultant reports and agency hydrogeological studies in the vicinity of the 4-S Ranch. Figure 4 is a generalized schematic of the aquifer system beneath the Stevinson and Merquin Water Districts, located approximately 3 miles north-west of the 4-S Ranch (BookmanEdmonston, 2003). This same structural profile of the local geology can be applied to the 4-S Ranch, given the similar location of both the 4-S Ranch and the Stevinson and Merquin Water Districts, which lie 
in the discharge area close to the San Joaquin Valley trough, east and adjacent to the San Joaquin River. The distal end of the sedimentary deposits between major alluvial fans are characterized by having finer sediment texture and are often discharge zones where water originating from higher elevations on the east side of the San Joaquin Valley is forced under pressure upward through the near surface formations to discharge into sloughs and other surface drainages into the San Joaquin River. Past drainage problems in the Stevinson and Merquin Water Districts are well documented due to a heavy reliance on surface water for irrigation water supply.

Figure 4 shows a depth profile of the major subsurface geologic units that are likely common to the 4-S Ranch property. Figure 5 is a generalized soils map for the study area obtained from the Natural Resource Conservation Service. Surface soils within the 4-S Ranch boundary are predominantly classified as Merced silt-loam. Both figures shows a shallow water table aquifer comprising of sandy-silt to silty sand sediments of Younger Alluvium that ranges between 50 and $100 \mathrm{ft}$ in thickness and that is interfingered by a sequence of clay lenses that is sometimes referred to as the "A" clay. The "A" Clay in this vicinity occurs typically at depths of between 15 and $50 \mathrm{ft}$ and may be up to $25 \mathrm{ft}$ thick. This inter-fingering of deposits is typical of alluvial fans where meandering streams have changed course and clay beds have been eroded and replaced with sand. Beneath the shallow water table aquifer is a better defined series of discontinuous clay lenses that makes up the Older Alluvium. The "C" Clay is a layer within the Older Alluvium. This sequence of interbedded clay and sand layers is typically from $10-60 \mathrm{ft}$ thick.

\subsection{Cone penetrometer (CPT) logging}

Cone Penetrometer Logging (CPT) was conducted at 4-S Ranch to develop a better understanding of the sedimentary geology of the semiconfined groundwater . During the CPT logging experiments, a conicalshaped probe instrumented with sensors was pushed into the ground up to depths of around $100 \mathrm{ft}$. The cone penetrometer used at 4-S Ranch contained sensors that continuously measured the friction sleeve, tip resistance, and electrical conductivity. A calibration curve was developed to convert bulk soil salinity measurements made with the CPT sensor to an equivalent soil solution salinity. Both Myron Inc. and YSI Inc. soil salinity sensors were used to develop this calibration curve. During the experiments it was noted that saturation occurred in the CPT electrode at bulk salinity concentrations above $600 \mathrm{mS} / \mathrm{m}$ - above this threshold the relationship between bulk salinity and EC became highly non-linear. Since the groundwater underlying much of the managed wetland area in the San Joaquin Valley has an EC below $9000 \mathrm{uS} / \mathrm{cm}-$ the non-linear portion of the calibration curve was eliminated and a best fit least squares calibration curve fitted (Figure 6).

The best-fit equation was shown to be :

$\mathrm{EC}(\mathrm{uS} / \mathrm{cm})=13.567 *$ bulk salinity $(\mathrm{mS} / \mathrm{m})$

This equation has a regression coefficient of $0.9983(\mathrm{mg} / \mathrm{l})$

Plots of the sensor data with depth and the subsequent soil types determined from this data are shown in Figures 7 through 9 for three locations on the 4-S Ranch. These locations correspond to the locations of three wells that were logged for water quality. The maximum depths of the CPT logs ranged from about 70 to $85 \mathrm{ft}$ in the three locations. The general soil profile from the CPT logs is consistent with the upper half of the profile shown in Figure 4. We observed a clay and sand layer, followed by a sand layer, a clayey sequence and a sand layer.

In Figure 7, the sand layers are found at about $22 \mathrm{ft}$ below the surface and extend down to about $65 \mathrm{ft}$ in this deep abandoned well. The highest permeability sand layer occurs in a depth interval of $24 \mathrm{ft}$ to 38 $\mathrm{ft}$ below the surface. A second clay layer shows up between $66 \mathrm{ft}$ and $71 \mathrm{ft}$ below the surface. Provided the sand layer is reasonably continuous this provides a reasonably extensive shallow aquifer for 


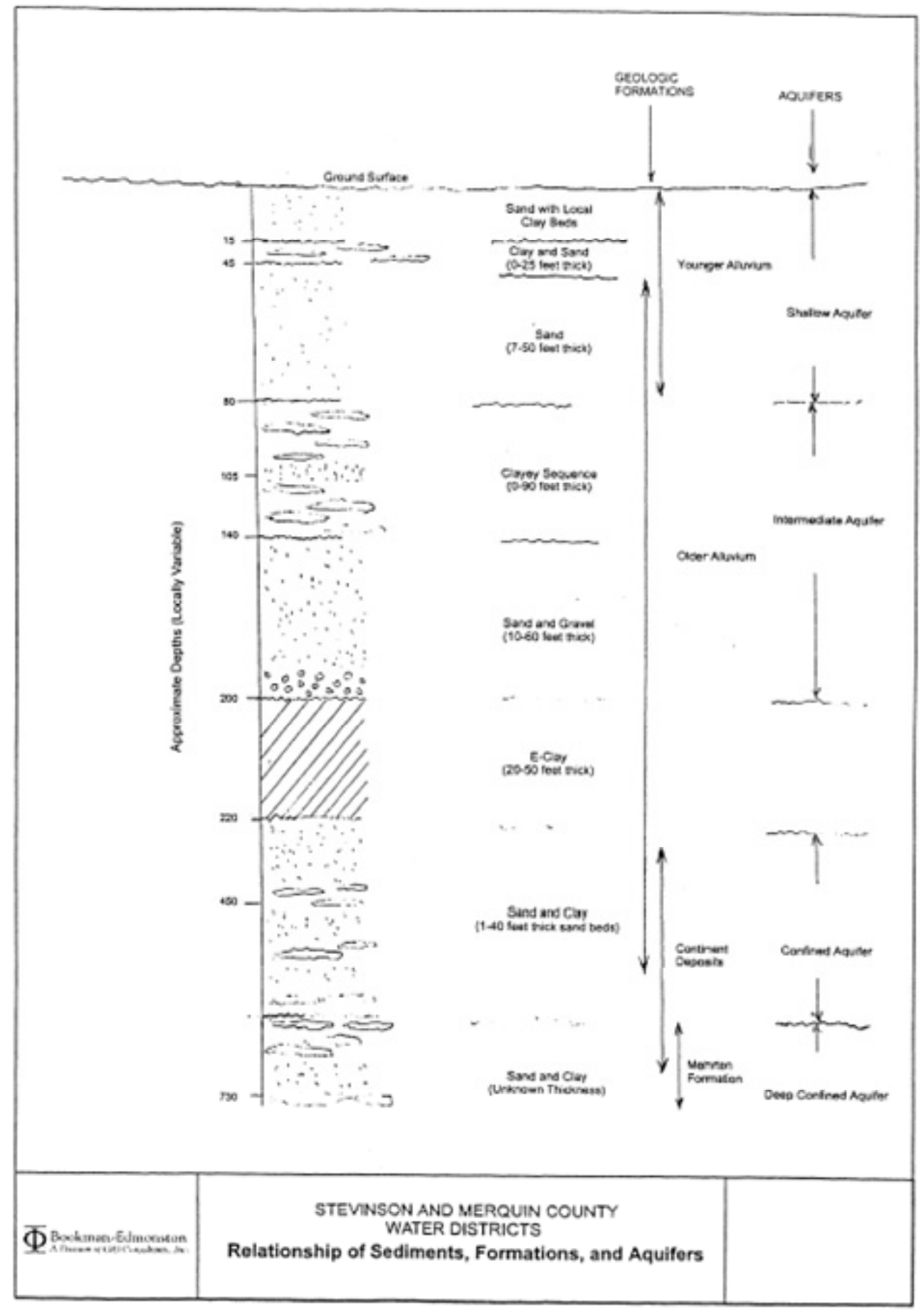

Figure 4. Generalized structural profile of sedimentary deposits and groundwater aquifers in the vicinity of the 4-S Ranch. (Source: Bookman-Edmonston, 2003). 

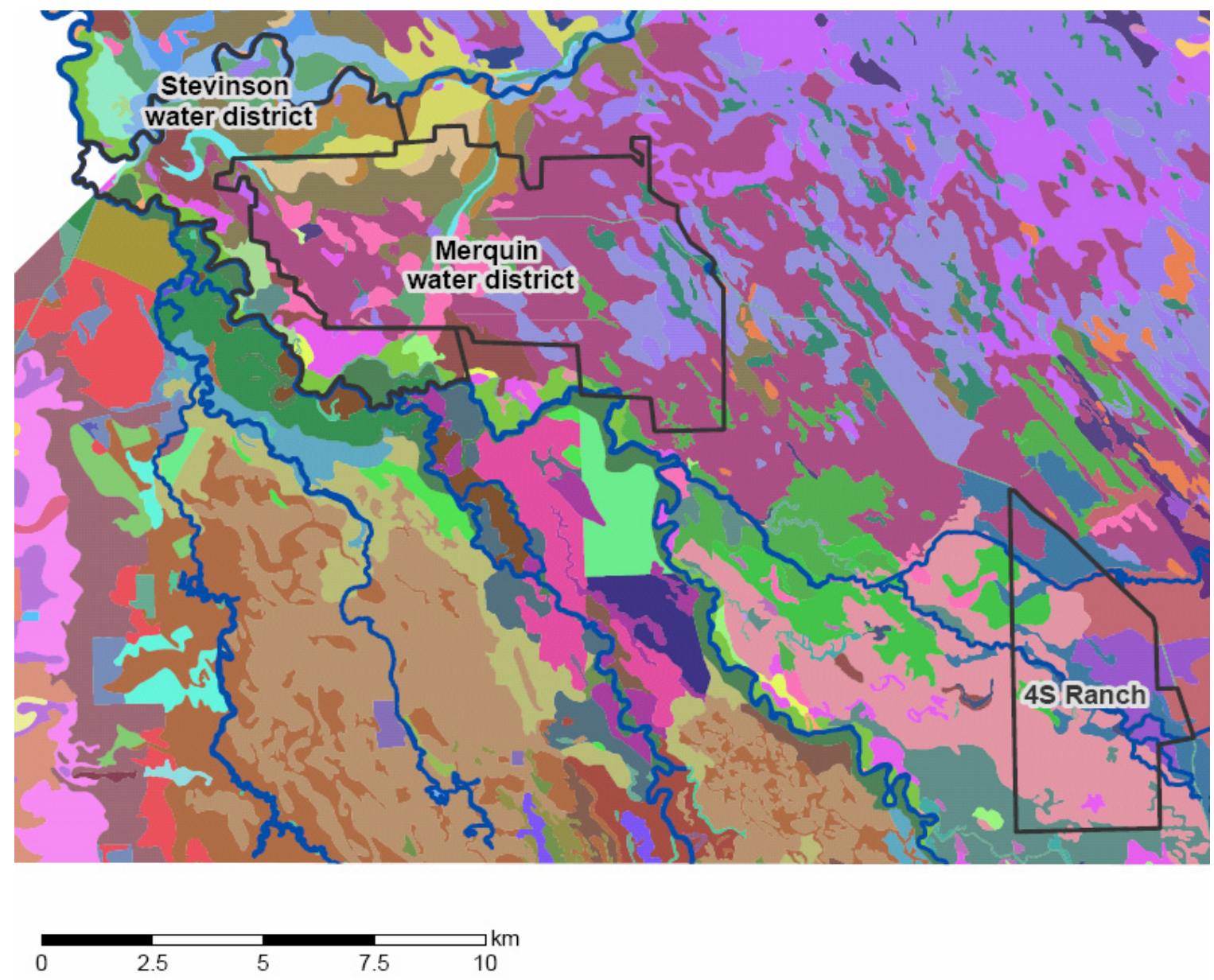

\section{Legend}

\begin{tabular}{|c|c|c|}
\hline Agnal clay loam & Edminster variant sand & Piper fine sandy loam \\
\hline Alros clay loam & Edminster-Kesterson complex & Piper soils \\
\hline Atwater loamy sand & EINido clay loam & Raynor clay \\
\hline Atwater sand & EINido sandy loam & Riverwash \\
\hline Bapos-Arburua complex & Fluvaquents & Rossi clay \\
\hline Bisgani clay loam & Foster fine sandy loam & Rossi clay loam \\
\hline Bisgani loamy sand & Fresno loam & SantaNela loam \\
\hline Bolfar clay loam & Grangeville fine sandy loam & Stanislaus-DosAmigos-Urbar \\
\hline Britto clay loam & Grangeville loam & Temple clay loam \\
\hline Burchell silt loam & Hanford fine sandy loam & Temple Ioam \\
\hline Chinvar loam & Hanford sandy loam & Traver fine sandy loam \\
\hline Columbia fine sandy loam & Hilmar loamy sand & Triangle clay \\
\hline Columbia loam & Himar sand & Tujunga loamy sand \\
\hline Columbia soils & Kesterson loam & Tujunga sand \\
\hline Deldota clay & Kesterson sandy loam & Turlock loam \\
\hline Delhi loamy fine sand & Kesterson-Edminster complex & Turlock sandy loam \\
\hline Delhi loamy sand & Landlow clay & Turmound sandy loam \\
\hline Delhi sand & Lewis clay & Volta clay loam \\
\hline Dello loamy fine sand & Lewis silty clay loam & Waukena fine sandy loam \\
\hline Dello sand & Marcuse clay & Waukena loam \\
\hline Dinuba sandy loam & Marcuse silty clay & Woo clay \\
\hline DosPalos clay & Merced clay & Woo clay loam \\
\hline DosPalos clay loam & Merced clay loam & Woo loam \\
\hline DosPalos-Bolfar complex & Merced silt loam & Woo-Urban complex \\
\hline Dosamigos clay & Pachappa fine sandy loam & water \\
\hline Dosamigos clay loam & Pachappa sandy loam & xerofluvents \\
\hline Dune land & Palazzo sandy loam & \\
\hline Edminster loam & Pedcat clay loam & \\
\hline & Pedcat loam & \\
\hline
\end{tabular}

Figure 5. Soils map of the study area showing the 4-S Ranch and adjacent water districts. 


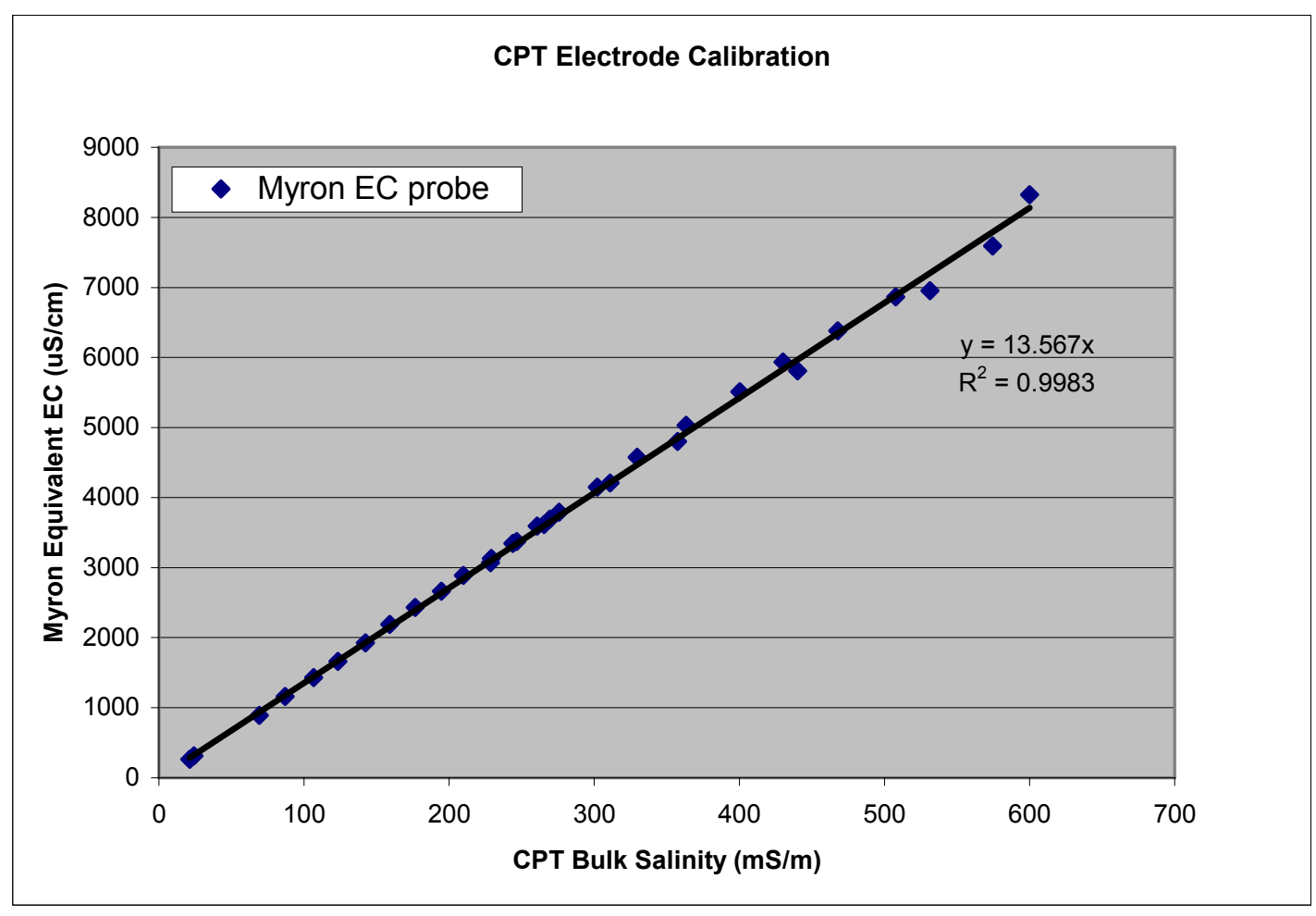

Figure 6. Calibration curve for converting CPT bulk salinity measurements $(\mathrm{mS} / \mathrm{m})$ to an equivalent groundwater EC (uS/cm).

exploitation. Bulk pore water salinity is elevated at the near surface (vadose zone) and diminishes to a concentration of about $50 \mathrm{mS} / \mathrm{m}(680 \mathrm{uS} / \mathrm{cm})$ below a depth of $18 \mathrm{ft}$. Water quality remains at this level until the probe reached a depth of $75 \mathrm{ft}$ whereupon it increased to $150 \mathrm{mS} / \mathrm{m}(2,035 \mathrm{uS} / \mathrm{cm})$.

In Figure 8, where the CPT $\log$ was taken adjacent to production well 7, a similar stratigraphy is observed to the abandoned well, although these observations were more than 1 mile apart. The CPT $\log$ shows a larger fraction of finer grade material. Silty sands and intermediate sand-silty sands predominate over an aquifer that lies between $22 \mathrm{ft}$ and $63 \mathrm{ft}$ below the surface. The porosity and the specific yield of these aquifer materials are lower than that of sand. A clay aquitard, probably the "C" Clay, that is approximately $15 \mathrm{ft}$ thick, lies immediately below the sand-silty sand aquifer. The water quality profile near production well 7 is similar to that at the abandoned well. Bulk salinity concentrations are high in the vadose zone but diminishes to under $50 \mathrm{mS} / \mathrm{m}(680 \mathrm{uS} / \mathrm{cm})$ until a depth of $62 \mathrm{ft}$ below where the concentration increases to $150 \mathrm{mS} / \mathrm{m}(2,035 \mathrm{uS} / \mathrm{cm})$.

The stratigraphy of the domestic well that was logged is shown in Figure 9. This well is on the northwest corner of the property and shows a significant layer of highly permeable sand at a depth below $30 \mathrm{ft}$. There is no distinct " $\mathrm{A}$ " clay at this location. The aquifer that sits above the "C" Clay is found at a depth range of $24 \mathrm{ft}$ to $67 \mathrm{ft}$ below the ground surface and is the most extensive and highest in average permeability of the three sites tested using the CPT logging technique. A very thin C clay aquitard is shown in the depth range of 67 to $69 \mathrm{ft}$ below the surface - the CPT couldn't penetrate any deeper than $72 \mathrm{ft}$ at this location and it is possible that the " $\mathrm{C}$ " clay is more extensive than shown. The water quality profile shows a poor water quality zone averaging $150 \mathrm{mS} / \mathrm{m}(2,000 \mathrm{uS} / \mathrm{cm})$ between $5 \mathrm{ft}$ and $23 \mathrm{ft}$ below the surface with a peak concentration of $300 \mathrm{mS} / \mathrm{m}(4,060 \mathrm{uS} / \mathrm{cm})$ at a depth of approximately 23 
$\mathrm{ft}$. Below this level water quality improves in the groundwater averaging $50 \mathrm{mS} / \mathrm{m}(680 \mathrm{uS} / \mathrm{cm})$ with a small increase to $100 \mathrm{mS} / \mathrm{cm}(1,350 \mathrm{uS} / \mathrm{cm})$ within $3 \mathrm{ft}$ of the bottom of the CPT logging profile.

\subsection{Groundwater quality logging}

Flowing fluid electric conductivity (FEC) logging was conducted in an open, abandoned well on the 4-S Ranch property. Measurements of the ambient electrical conductivity (EC) with depth of two other wells on 4-S were also logged. As described by Tsang and Doughty (2003), the flowing FEC logging method involves first replacing the well bore water by de-ionized water or water of a constant salinity distinctly different from that of the formation water. This is done by injecting de-ionized water down a tube to the bottom of the well, while simultaneously pumping from the top of the well, until the EC of the water pumped out of the well stabilizes at a low value. Next, the pumps are turned off and the well is pumped only from the top at a constant low flow rate, while an electrical conductivity probe is lowered into the borehole to record the EC as a function of depth and time.

\subsubsection{Open, Abandoned Well}

The FEC logging conducted in the open, abandoned irrigation well on 4-S Ranch which was perforated from a depth of $121 \mathrm{ft}$ below ground surface to the bottom of the well. The well depth was estimated to be approximately $223 \mathrm{ft}$ (Figure 10). The water in this well was around $26 \mathrm{ft}$ below ground surface. Deionizing filters were used to reduce the salinity of the well water that was extracted. The extracted water was run through the filters and then the de-ionized water was injected into the well. The water was extracted/injected at a rate of $3.6 \mathrm{gal} / \mathrm{min}$ over a period of 5 hours.

After the 5 hour period of replacing the well bore water, the injection pump was shut off and only the extraction pump was on at a rate of $5 \mathrm{gal} / \mathrm{min}$, and the EC profile in the well was logged for the next 3 hours. The initial EC profile in the well before water was extracted/injected and the subsequent hourly EC profiles after the water replacement had ceased and water was only extracted are presented in Figure 10. Over the screened interval, the initial EC profile is nearly uniform at $1350 \mathrm{uS} / \mathrm{cm}$ (or $1.35 \mathrm{mS} / \mathrm{cm}$ ) except for a peak near the top of the well screen between $121 \mathrm{ft}$ to $131 \mathrm{ft}$. After injecting the deionized water, the EC decreases to around $600 \mathrm{uS} / \mathrm{cm}$ between 164 and $220 \mathrm{ft}$ and then increases to $950 \mathrm{uS} / \mathrm{cm}$ between 141 and $164 \mathrm{ft}$. The peak present in the initial profile was still present after the de-ionized water was injected, indicating that flow into the well at that particular location is higher than in the rest of the well. The increase in EC in the interval 141 to $164 \mathrm{ft}$ is because of vertical mixing of the higher EC water with the lower EC water below. The higher EC water entering the well around $121 \mathrm{ft}$ propagated up the well bore over time, whereas the higher EC water entering around $141 \mathrm{ft}$ propagated downward over time most likely because of vertical head gradients.

\subsubsection{Ambient EC Profiles}

Ambient EC profiles with depth were logged in two other wells on 4-S Ranch: an irrigation well (Well 7) that is still actively used and a domestic well. FEC logging was not conducted in these wells. The plots are shown in Figures 11 and 12. The borehole camera was not available when these wells were logged so we were not able to get the screened intervals. Well 7 had multiple screened intervals according to the caretaker of the 4-S Ranch property. The abrupt changes in the EC with depth are probably because of these multiple screens. The EC in this well is fairly low, ranging between 0.5 to 0.6 $\mathrm{mS} / \mathrm{cm}$. The EC in the domestic well increases nearly linearly from the top to the bottom from around $0.8 \mathrm{mS} / \mathrm{cm}$ to nearly $1.2 \mathrm{mS} / \mathrm{cm}$. The linear change in EC indicates that this well may be screened only at the bottom of the well casing. 


\section{Bureau of Reclamation}

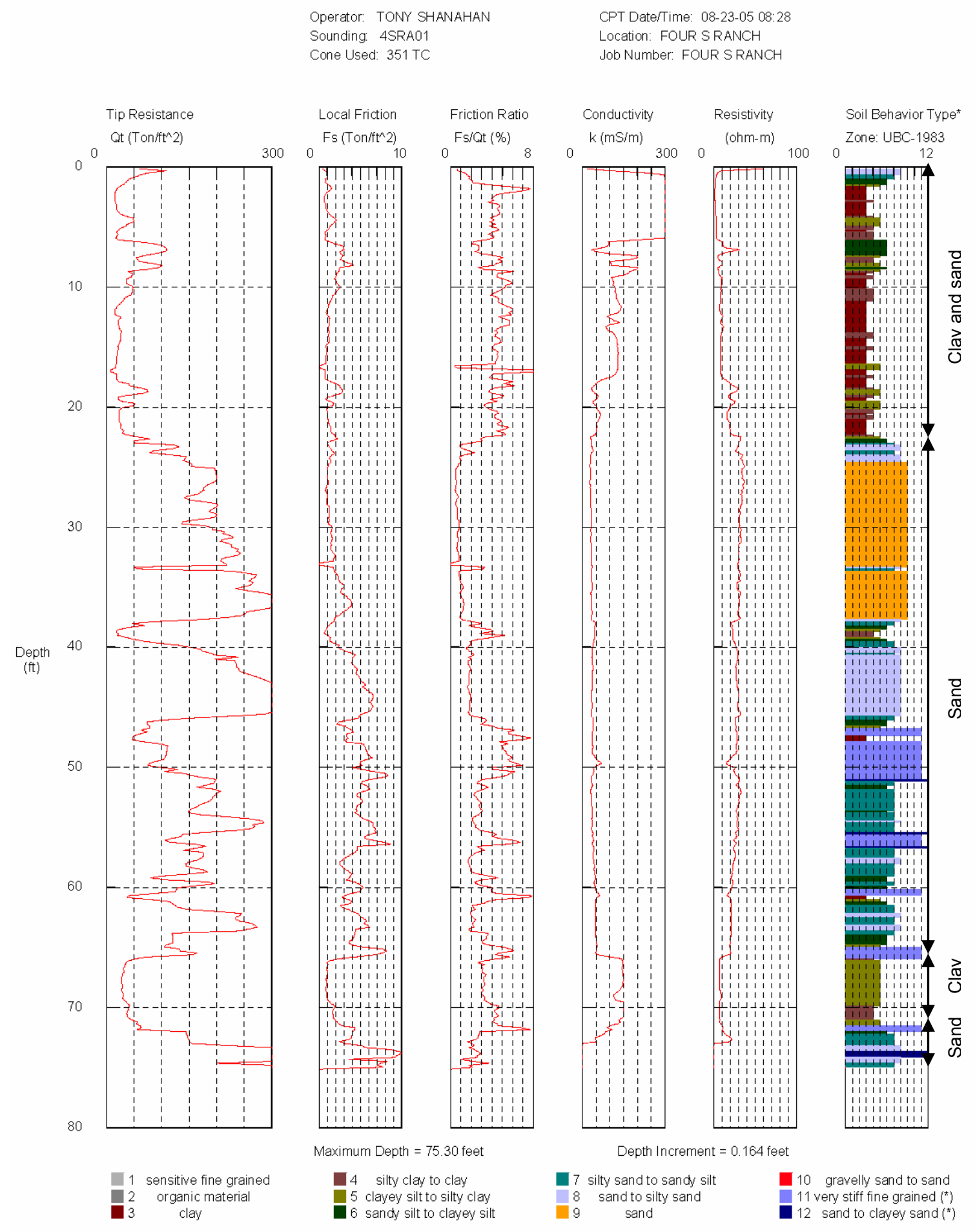

*Soil behavior type and SPT based on data from UBC-1983

Figure 7. CPT log for the abandoned well near Owens Creek on the 4-S Ranch. 


\section{Bureau of Reclamation}

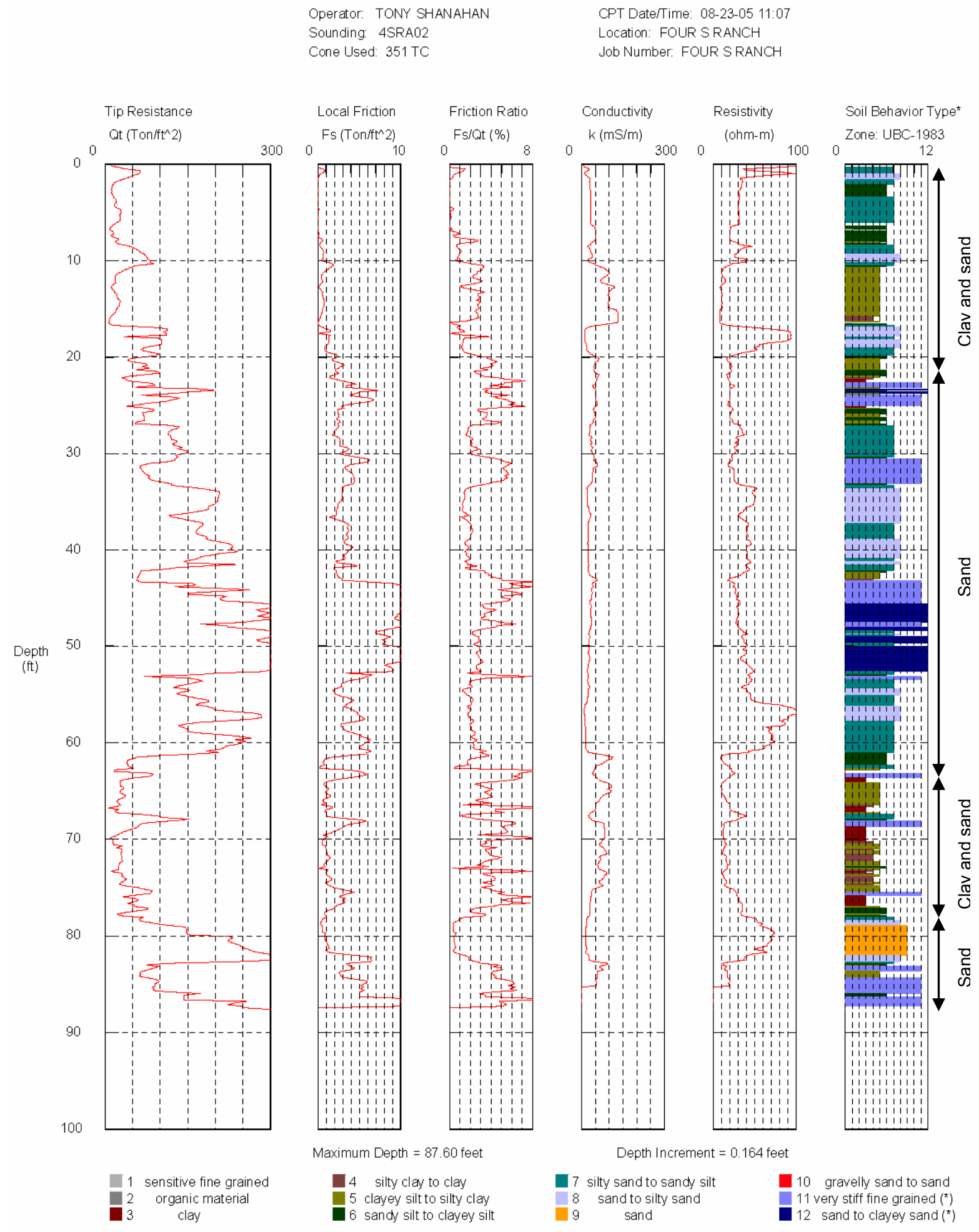

*Soil behavior type and SPT based on data from UBC-1983

Figure 8. CPT log for production well no. 7 on the 4-S Ranch. 


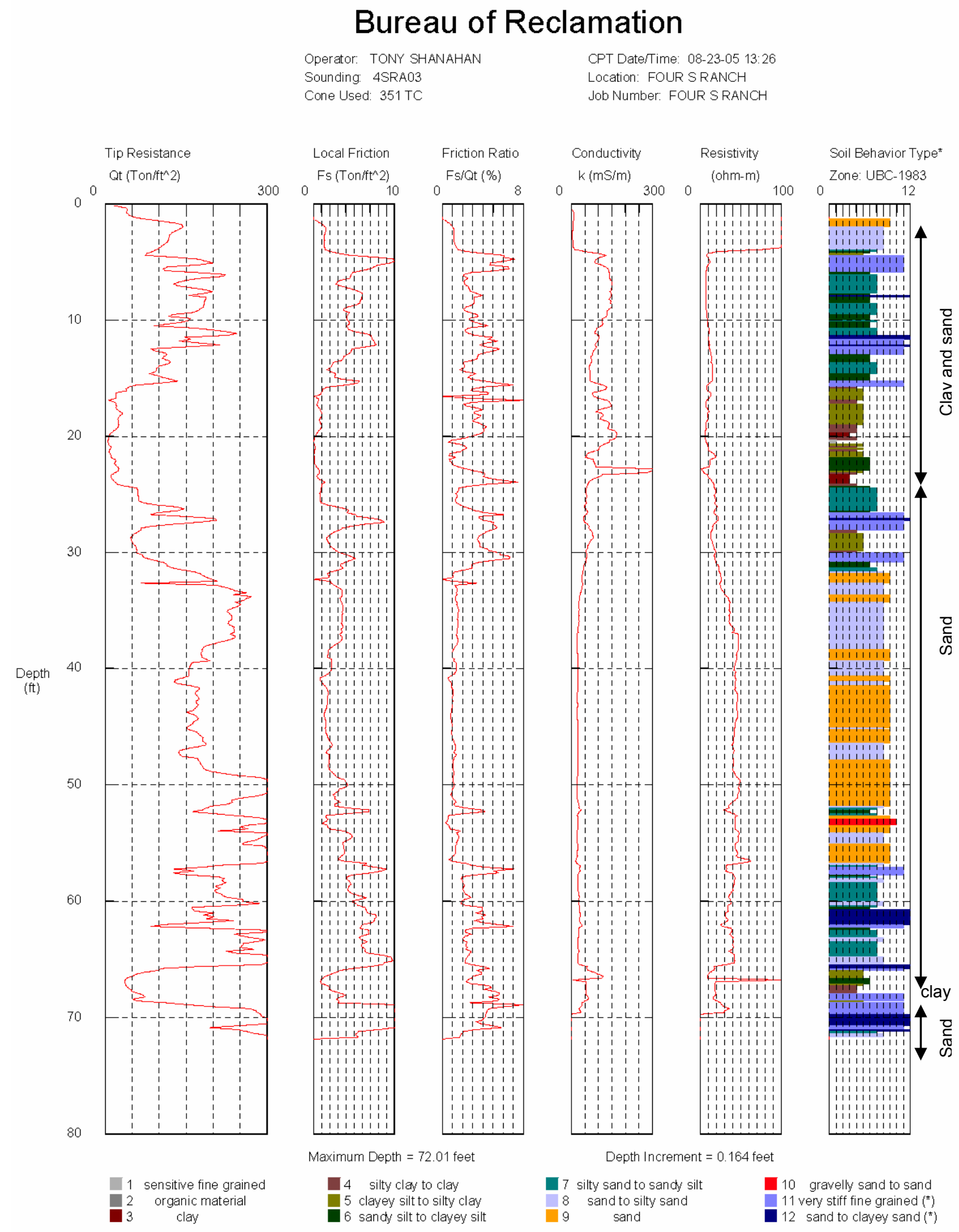

*Soil behavior type and SPT based on data from UBC-1983

Figure 9. CPT $\log$ for the domestic well in north-west corner of the 4-S Ranch. 


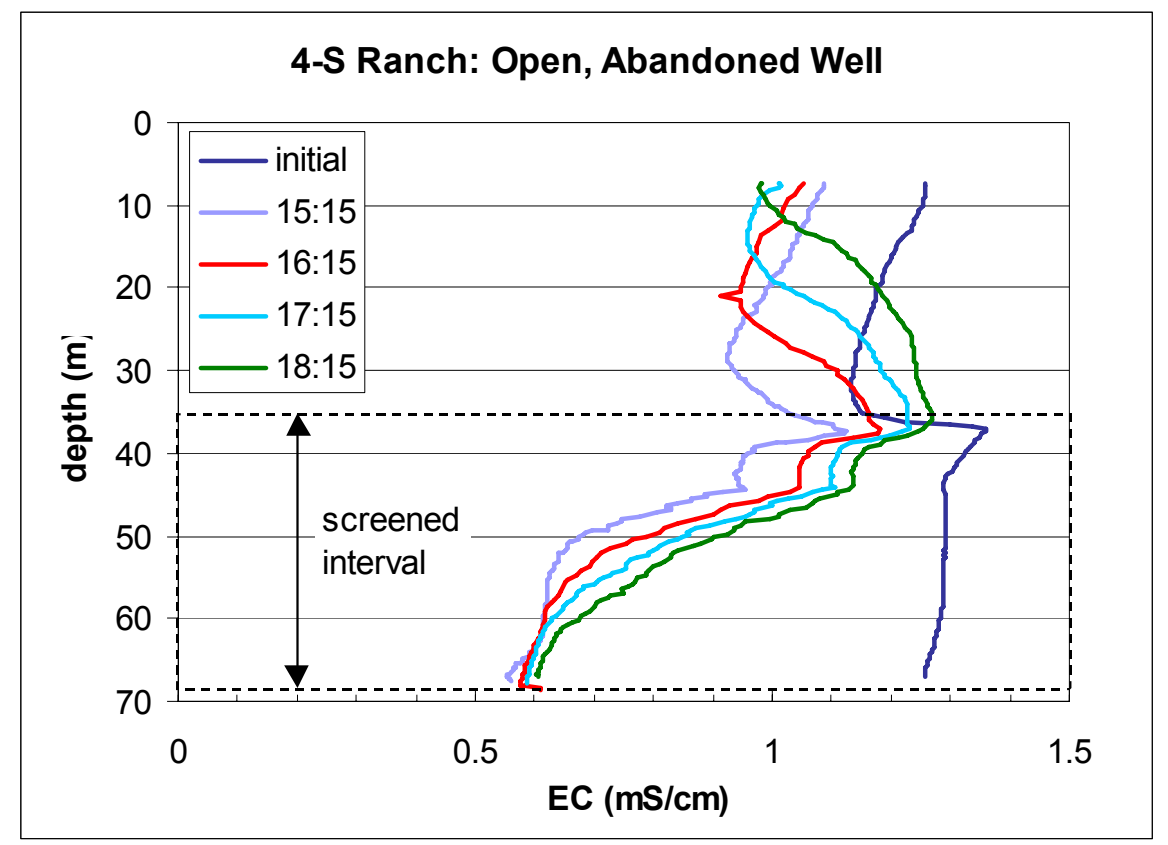

Figure 10. FEC logging profiles at different times at the open abandoned well at 4-S Ranch. The times during which the logging took place are indicated in the legend. The water level in this well was initially at $26 \mathrm{ft}$ below the ground surface.

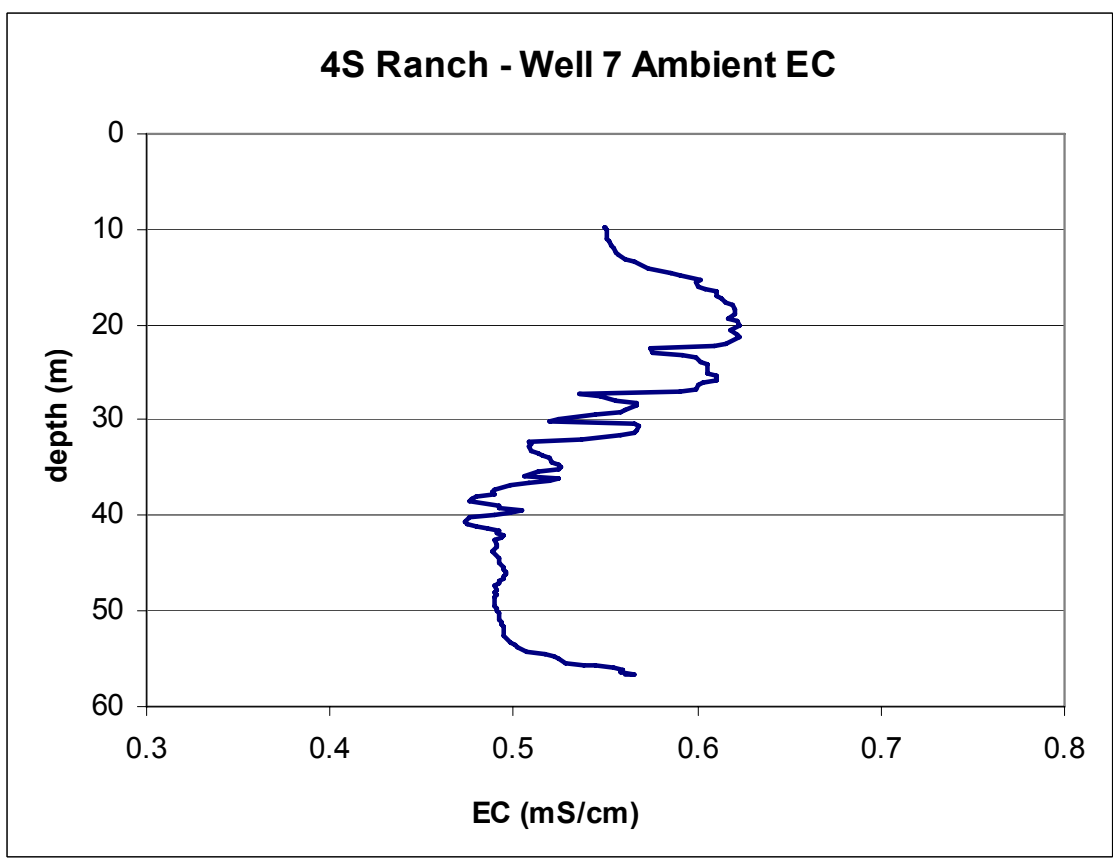

Figure 11. Ambient EC log of Well 7 on 4-S Ranch. Water quality logging was not possible owing to lack of an access port of sufficient diameter though which to pass the probe. 


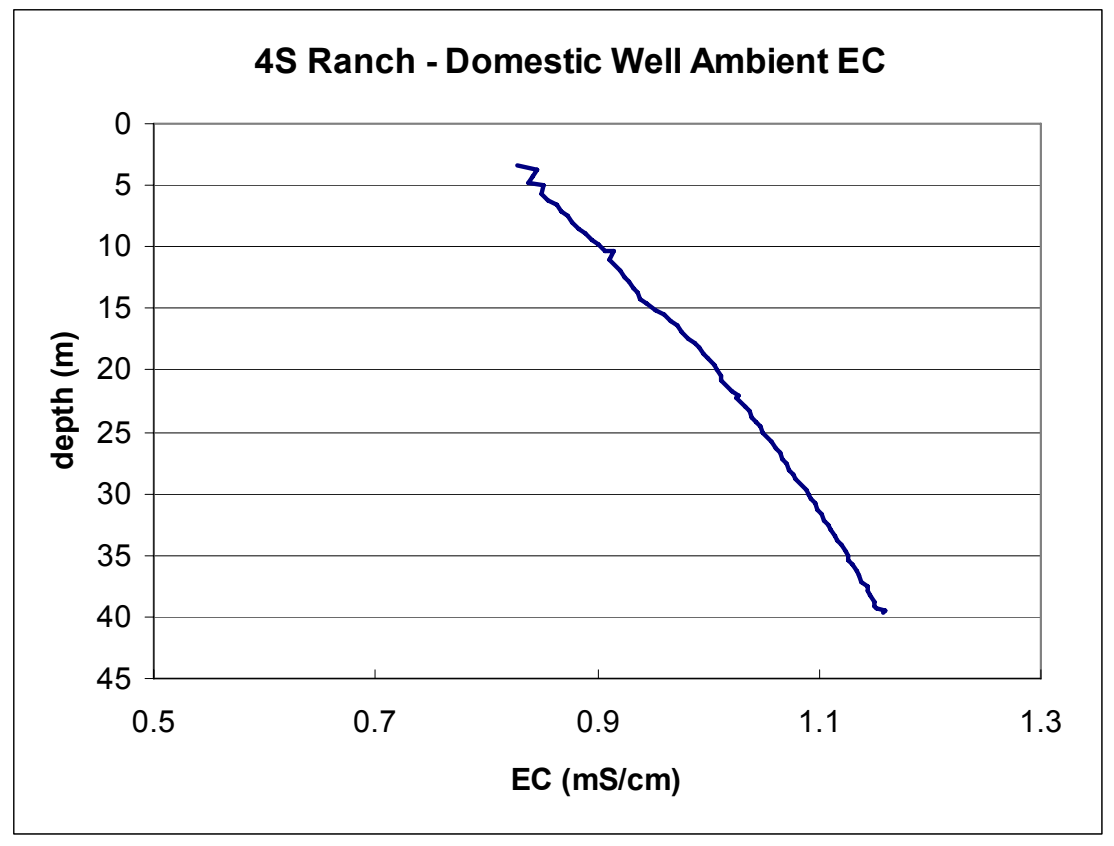

Figure 12. Ambient EC log of the domestic well on 4-S Ranch.

\subsection{Subregional groundwater quality}

Regional groundwater quality has been described as highly variable in studies by Bookman-Edmonston (2003, 2005) and Schmidt (2005). Water quality in the above- Corcoran semi-confined aquifer is affected by the regional flow system that is influenced by recharge from local streams and surface water conveyances and drainage into the San Joaquin River to the west. Whereas some newer man-made channels which cut through sandy formations within the shallow groundwater aquifer and may experience high rates of seepage - older natural channels may seal over time as fine grained materials plug the interstices between sand grains and hence experience low rates of seepage. In the latter case the rate of seepage is dictated by the permeability of the streambed rather than the permeability of the shallow aquifer. Figure 13 illustrates three different hydrogeological scenarios that occur within the groundwater basin - some of which may change seasonally, that can have a significant impact on the depth distribution of salts and other contaminants within the semiconfined aquifer.

The majority of the wells that are installed within the 4-S Ranch are located along the alignment of the Eastside Canal and are greatly influenced by seepage from this conveyance facility. The salinity of the groundwater pumpage is therefore moderate to low - represented by the ambient water quality of Well 7 , depicted in Figure 11 - typically in the range of $500-600 \mathrm{uS} / \mathrm{cm}$. Wells such as the domestic well and the open, abandoned well, shown in Figures 10 and 12, show maximum EC's in the range of 1,100 uS/cm to $1,500 \mathrm{uS} / \mathrm{cm}$. The quality of the groundwater pumped by these wells is affected mostly by the quality of the surface water applied to the pasture as irrigation, residual salts that might be dissolved from the aquifer materials through which this percolating water infiltrates and by concentration by the process of evapotranspiration while in the vadose zone. Since the 4-S Ranch is located at the distal margins of the Eastside alluvial fans formed from eroded Sierra Nevada sediments, groundwater quality is expected to be comparable to that measured within the Stevinson and Merquin Water Districts. 
Bookman-Edmonston (2003) conducted EC measurements for most of the production wells in both Districts during 2002 and 2003. These data are presented in Table 1. The table shows that all wells are developed within the semiconfined aquifer above the Corcoran (E-Clay) Clay. Many wells in the Merquin Water District, which is located in a similar juxtaposition to the San Joaquin River as the 4-S Ranch, are screened between 30 and $200 \mathrm{ft}$. to maximize well yield by tapping high yielding sand formations and to exploit regional groundwater flows towards the San Joaquin River from the Merced Irrigation District to the east. The best quality water in the semi-confined aquifer is usually to be found immediately above the Corcoran Clay. The mean EC of these wells is $924 \mathrm{uS} / \mathrm{cm}$ (Table 1). This is similar to the ambient EC of the domestic well on the 4-S Ranch (Figure 12).
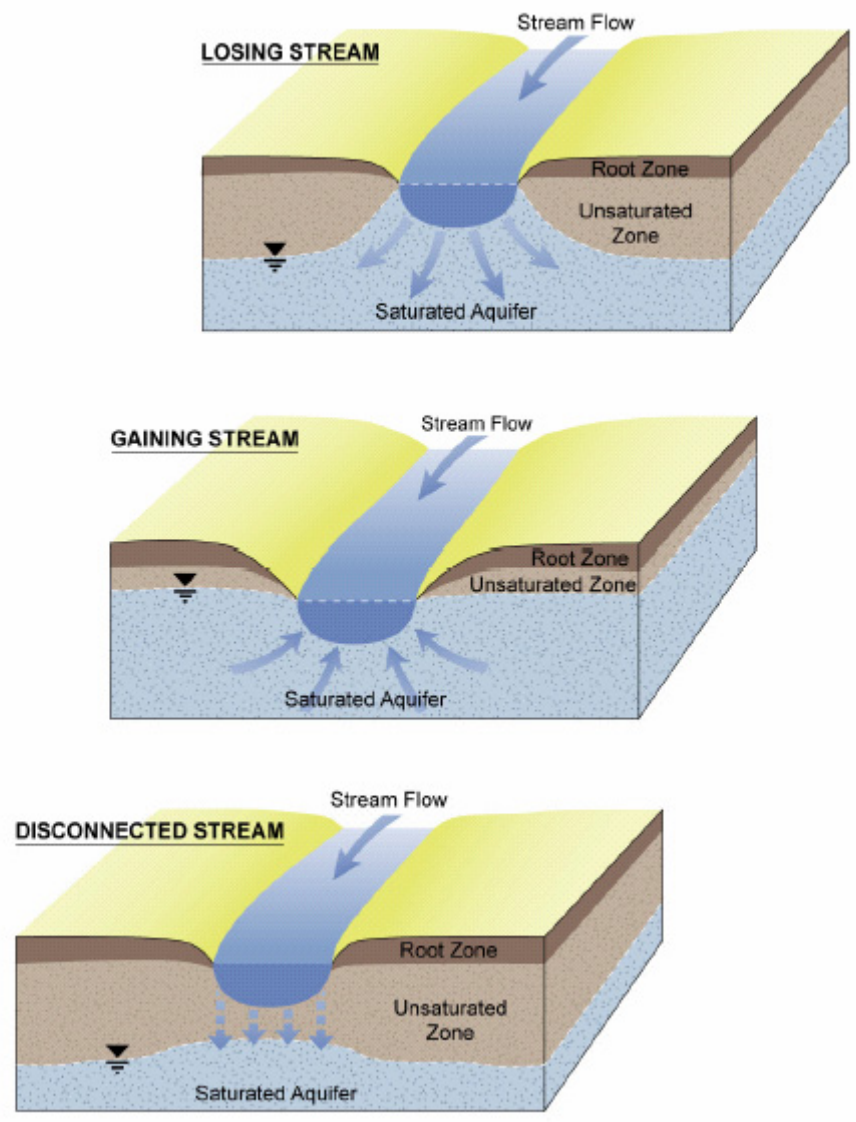

Figure 13. Illustration of canal and river seepage scenarios relevant to 4-S Ranch.

\subsection{Groundwater Pumping}

Groundwater pumpage rates for the 4-S Ranch are obtained from the Pump Test Reports prepared by the Anderson Pump Company, which tested and rehabilitated several of the wells on the property in October 2004 (Appendix A). These test reports also provide information on the specific capacity of the wells, the maximum drawdown of the water level during pumping, the total pump lift, measured flow rate and cost of groundwater pumping based on the cost of power in October 2004 (Table 2). The pumping rates shown in Table 2 are higher than the average pumping rates for the Merquin Water District $(700-1,500$ gpm) and comparable to the rates for the Stevinson Water District (800 - 4,200 gpm) (Schmidt, 2005) 
which is located closer to the trough of the San Joaquin Basin and in coarser grained surface sediments (Figure 4). 


\begin{tabular}{|c|c|c|c|c|c|c|c|}
\hline $\begin{array}{l}\text { WELL } \\
\text { ID }\end{array}$ & $\begin{array}{c}\text { Well } \\
\text { diameter } \\
\text { (inches) }\end{array}$ & $\begin{array}{l}\text { Total } \\
\text { depth } \\
\text { (feet) }\end{array}$ & $\begin{array}{c}\text { Perforated } \\
\text { interval (feet) }\end{array}$ & $\begin{array}{l}\text { Gravel } \\
\text { pack } \\
\text { interval } \\
\text { (feet) }\end{array}$ & $\begin{array}{c}\text { Pumpage EC } \\
\text { umhos/cm } \\
(2001-2002)\end{array}$ & $\begin{array}{l}\text { * Pump } \\
\text { capacity } \\
(\mathrm{gpm})\end{array}$ & $\begin{array}{l}* * \text { Pump } \\
\text { capacity } \\
(\mathrm{Ac}-\mathrm{ft} / \mathrm{yr})\end{array}$ \\
\hline \multicolumn{8}{|c|}{ MERQUIN WATER DISTRICT $(11,270$ acres $)$} \\
\hline M1 & 16 & 170 & $60-160$ & $0-160$ & 1160 & 845 & 336 \\
\hline M2 & 16 & 180 & $30-174$ & $0-180$ & 1520 & 718 & 286 \\
\hline M3 & 16 & 133 & $30-130$ & $0-130$ & 1490 & 856 & 340 \\
\hline M4 & 16 & 184 & $30-174$ & $0-184$ & 510 & 982 & 391 \\
\hline M5 & 16 & 190 & $30-180$ & $0-190$ & 500 & 716 & 285 \\
\hline M6 & 16 & 180 & $30-170$ & $0-180$ & 500 & 833 & 331 \\
\hline M7 & 16 & 172 & $30-160$ & $0-172$ & 760 & & \\
\hline M8 & 16 & 158 & $30-160$ & $0-168$ & 720 & 949 & 377 \\
\hline M9 & 16 & 158 & $30-150$ & $0-158$ & 1420 & 804 & 320 \\
\hline M10 & 16 & 196 & $30-186$ & $0-196$ & & 1023 & 407 \\
\hline M11 & 16 & 180 & $60-170$ & $0-180$ & 750 & 1502 & 597 \\
\hline M12 & & & & & 1160 & 755 & 300 \\
\hline M13 & 16 & 187 & $60-180$ & $0-187$ & 890 & 1061 & 422 \\
\hline M14 & 16 & 135 & $30-130$ & $0-135$ & 890 & 885 & 352 \\
\hline M15 & 16 & 245 & $90-230$ & $0-245$ & 770 & 1667 & 663 \\
\hline M16 & 16 & 205 & $60-200$ & $0-205$ & 1110 & 1279 & 509 \\
\hline M17 & 16 & 127 & $20-120$ & $0-127$ & 790 & 1111 & 442 \\
\hline M18 & 16 & 190 & $80-165$ & $50-265$ & 750 & 975 & 388 \\
\hline M19 & 16 & 220 & $60-120$ & $0-220$ & 750 & 1155 & 459 \\
\hline M20 & 16 & 220 & $90-120$ & $0-220$ & 1240 & 1527 & 607 \\
\hline M21 & 16 & 160 & $30-156$ & $0-160$ & & 583 & 232 \\
\hline \multirow[t]{2}{*}{ M22 } & 16 & 220 & $80-195$ & 50-195 & 800 & 413 & 164 \\
\hline & & & & & & Total & 8,209 \\
\hline \multicolumn{8}{|c|}{ STEVINSON WATER DISTRICT $(7,560$ acres $)$} \\
\hline S2 & 18 & 180 & $90-180$ & $50-180$ & & & 1153 \\
\hline S3 & 18 & 144 & $60-140$ & $0-150$ & 638 & 1450 & 577 \\
\hline S4 & 18 & 144 & $60-144$ & $0-153$ & 1581 & 2300 & 915 \\
\hline S5 & & & & & 1660 & 1732 & 689 \\
\hline S6 & 18 & 250 & $90-250$ & $20-250$ & 1654 & 3500 & 1392 \\
\hline S7 & 18 & 186 & $90-186$ & $0-186$ & 1520 & 2300 & 915 \\
\hline S8 & 18 & 168 & $54-168$ & $0-220$ & 824 & 1500 & 597 \\
\hline SD20 & 8 & 120 & $100-120$ & 84-120 & & 40 & \\
\hline S10 & 18 & 198 & $80-198$ & $50-198$ & 888 & 2000 & 796 \\
\hline S11 & 12 & 170 & $95-170$ & $75-170$ & & 1349 & 537 \\
\hline S12 & 18 & 240 & $120-240$ & $0-253$ & 624 & 4200 & 1671 \\
\hline S13 & 18 & 192 & $\begin{array}{c}78-106 / 134- \\
162\end{array}$ & $50-192$ & & 3980 & \\
\hline S14 & 16 & 162 & $72-162$ & $0-169$ & & 1100 & 438 \\
\hline S15 & 16 & 162 & $72-162$ & $0-165$ & & 2034 & 809 \\
\hline S16 & 12 & 160 & $50-160$ & $40-160$ & 2160 & 800 & 318 \\
\hline S17 & 18 & 164 & $84-164$ & $50-164$ & & 1257 & 500 \\
\hline $\mathrm{S} 18$ & 16 & 205 & $65-205$ & $50-205$ & 1009 & 1800 & 716 \\
\hline \multirow[t]{2}{*}{ S19 } & 8 & 135 & $105-135$ & $75-135$ & & 60 & \\
\hline & & & & & & Total & 12,021 \\
\hline
\end{tabular}


Table 1. Well construction information and ambient EC in wells located in the Stevinson and Merquin Water Districts during 2002 and 2003.

\begin{tabular}{|c|c|c|c|c|c|c|}
\hline $\begin{array}{c}\text { Pump } \\
\text { No. }\end{array}$ & $\begin{array}{c}\text { Total Pump } \\
\text { Lift } \\
(\mathrm{ft})\end{array}$ & $\begin{array}{c}\text { Measured } \\
\text { flow rate } \\
(\mathrm{gpm})\end{array}$ & $\begin{array}{c}\text { Standing } \\
\text { water } \\
\text { level } \\
(\mathrm{ft})\end{array}$ & $\begin{array}{c}\text { Water } \\
\text { table } \\
\text { drawdown } \\
(\mathrm{ft})\end{array}$ & $\begin{array}{c}\text { Specific capacity } \\
\text { of well } \\
(\mathrm{gpm} / \mathrm{ft} \text { of } \\
\text { drawdown })\end{array}$ & $\begin{array}{c}\text { Cost/acre-ft } \\
(2004 \text { power cost } \\
\text { per Kwh) }\end{array}$ \\
\hline 1 & 39 & 1870 & 9 & 17 & 110 & $\$ 10.30$ \\
2 & 73 & 2504 & 13 & 47 & 70 & $\$ 8.49$ \\
4 & 70 & 2310 & 29 & 33 & 70 & $\$ 11.04$ \\
5 & 68 & 1840 & 14 & 49 & 38 & $\$ 11.59$ \\
6 & 66 & 2071 & 13 & 43 & 48 & $\$ 10.21$ \\
7 & 74 & 1749 & 21 & 47 & 37 & $\$ 13.13$ \\
8 & 106 & 1584 & 12 & 85 & 19 & $\$ 16.04$ \\
9 & 59 & 1402 & 13 & 40 & 35 & $\$ 12.33$ \\
10 & 42 & 2343 & 14 & 22 & 107 & $\$ 8.34$ \\
11 & 119 & 1171 & 13 & 98 & 12 & $\$ 22.27$ \\
\hline
\end{tabular}

Table 2. Pump Test Reports completed in October 2004 for existing production wells on the 4-S Ranch.

Analysis of the test data in Table 2 provides another example of the wide spread in well specific capacity. Specific capacity in the existing production wells vary from a low of $12 \mathrm{gpm} / \mathrm{ft}$ of drawdown to a high of $107 \mathrm{gpm} / \mathrm{ft}$ of drawdown. The general conclusion drawn from the pump tests is that seepage from the Eastside Canal is likely sufficient to allow sustainable pumping at the rated discharge of the installed production wells. It is unlikely that the same pumping rates can be achieved from newly installed wells in locations other than along the alignment of the Eastside Canal, given that the Canal contains water mostly year-around, unlike Bear Creek and the Mariposa Bypass which convey seasonal flows.

\begin{tabular}{|ccccc|}
\hline Aquifer & Area (acres) & $\begin{array}{c}\text { Average estimated } \\
\text { aquifer thickness } \\
\text { (ft) }\end{array}$ & $\begin{array}{c}\text { Estimated } \\
\text { specific yield } \\
\text { (percent) }\end{array}$ & $\begin{array}{c}\text { Average } \\
\text { groundwater in } \\
\text { storage (acre-ft) }\end{array}$ \\
\hline $\begin{array}{c}\text { Shallow aquifer } \\
\text { Merquin WD }\end{array}$ & 5400 & 70 & 10.9 & 41,000 \\
$\begin{array}{c}\text { Deep semi- } \\
\text { confined aquifer }\end{array}$ & 5400 & 100 & 11.3 & 61,000 \\
\hline
\end{tabular}

Table 3. Estimated groundwater volume in storage beneath the 4-S Ranch using aquifer parameter values derived from the Merquin and Stevinson geohydrologic studies. 


\subsection{Groundwater Resource Evaluation}

The volume of groundwater in storage can be estimated using the average estimated aquifer thickness and the estimated specific yield of the aquifer. Well logs were not available for the 4-S property nor were any of the wells tested deep enough to penetrate the entire above-Corcoran Clay aquifer. In the case of the CPT logging experiments - the cone truck can only typically achieve depths of $70-100 \mathrm{ft}$ before the truck starts lifting owing to the high sliding friction on the cone penetrometer. Exceeding the applied load can cause a rod to stick or if the cone truck is pushed out of alignment can cause bent or damaged rods. Since well data was not available for the 4-S Ranch the estimated aquifer thickness and estimated aquifer specific yield are taken from data for the Merquin Water District.

Table 3 suggests that there is approximately 100,000 acre- $\mathrm{ft}$ of groundwater in storage beneath the 4-S Ranch. Sustainable exploitation of this groundwater resource depends on the rate of groundwater recharge derived from deep percolation of irrigated water and seepage from canals and conveyance structures that border the 4-S Ranch (Bear Creek and the Eastside Bypass) that cut through the central and northern ends of the 4-S Ranch. Fallowing of the 4-S Ranch to provide water supply to adjacent refuges will remove a significant component of annual groundwater recharge.

\subsection{Groundwater levels and aquifer safe yield}

Groundwater level data has not been routinely collected for the 4-S Ranch hence there are no hydrographs to show trends in groundwater levels over time. Hydrographs obtained for the Merquin Water District show that water levels have remained reasonably constant over time. This implies, at least for Merquin Water District, that the combination of regional groundwater inflow from the Merced Irrigation District upslope, deep percolation of irrigation application and deep percolation of winter rainfall is sufficient to restore the aquifer to its original state. Total recharge from deep percolation and canal seepage to Merquin and Stevinson Water Districts has been estimated to be about 16,400 acre-ft/yr or about 0.9 acre-ft/acre-yr (Schmidt, 2005). The maximum rate of aquifer groundwater pumping that does not exceed the recharge is known as the safe yield.

In the case of the 4-S Ranch the current rate of pumping from wells No. 1-11 (10 wells - no well no. 3) located on the alignment of the Eastside Canal does not appear to exceed the aquifer safe yield. Well recovery was shown to be quite rapid for several of the wells tested because of groundwater inflow from the east. There is not enough data to determine the safe yield for any new pumping that might occur within the property boundary of the 4-S Ranch. Recharge rates to the aquifer are a combination of effective rainfall, deep percolation of surface irrigation water and groundwater inflow that might cross into the 4-S Ranch en-route to the San Joaquin River. If the figure of 0.9 acre-ft/acre-yr is applied to the entire 4-S Ranch property that would amount to a pumpable groundwater yield of $4860 \mathrm{acre}-\mathrm{ft} / \mathrm{yr}$. If an assumption is made that irrigation wells pump on average $50 \%$ of the time during the irrigation season between April and September each year (approximately 90 days - same assumption made by BookmanEdmonston, 2003) - then using the pumpage rates from the test reports in Appendix A yields an average annual pumpage of 7,000 acre-ft/yr from the ten active production wells located along the property boundary and the alignment of the Eastside Canal.

\section{FINDINGS AND RECOMMENDATION}

Hydrogeological assessment of the 4-S Ranch was conducted using a combination of field investigations and a survey of available literature from nearby agricultural water districts. Pump records and pump performance data were obtained from the Anderson Pump Company. However the company that originally drilled and developed the various production wells on the 4-S Ranch is no longer in business and well logs could not be obtained. The 4-S Ranch has been able to meet most of its own water needs providing irrigated pasture for beef cattle by an active program of shallow groundwater pumping in the 
semiconfined aquifer above the Corcoran Clay. Comparison of groundwater pumping on the 4-S Ranch property with groundwater pumping in the adjacent Merquin and Stevinson Water Districts shows great similarity in the well screened depths and the quality of the groundwater produced by the well fields. The pump yield for the ten active production wells on the 4-S property are comparable to the production and drainage wells in the adjacent Districts. Like these Districts the 4-S Ranch lies close to the San Joaquin Valley trough in a historic discharge area. Groundwater pumping in the adjacent water districts has become necessary for shallow water table control.

The 4-S Ranch is bounded and bisected by several major water conveyance facilities including Bear Creek. The Eastside Canal runs along the north-eastern and eastern boundaries of the Ranch and the Mariposa Bypass forms the southern border. The Eastside Bypass and Bear Creek run through the Ranch in a south-east to north-west orientation. Although the large number of potential recharge facilities would suggest significant groundwater conjunctive use potential - the major well field development has occurred along the length of the Eastside Canal. The Eastside Canal is known to be leaky and passes through sandy areas which allow significant groundwater seepage which can be intercepted by adjacent groundwater wells. This pumping may induce higher levels of seepage below certain reaches of the Canal. Water quality below and adjacent to the Canal (most of the pumpage occurs in a depth interval between $30 \mathrm{ft}$ and $130 \mathrm{ft}$ ) is very good, reflecting the origin of this diverted water from the Merced River. The few wells that are close to the Eastside Bypass, Bear Creek and Owens Creek appear to tap groundwater deeper in the semi-confined aquifer which is poorer in water quality.

Safe yield estimates made using the available data show that the 4-S Ranch has sufficient groundwater resources to meet its own existing needs. If an assumption is made that the existing irrigation wells pump on average $50 \%$ of the time during the irrigation season between April and September each year (approximately 90 days) - then using the pumpage rates for the test reports in Appendix A yields an average annual pumpage of 7,000 acre-ft/year from the ten production wells located along the property boundary and the alignment of the Eastside Canal. Should any future lining of the Eastside Canal occur, it would very likely significantly impact the existing groundwater yield of the 4-S Ranch and impair the overall quality of the available water supply.

There is not enough data to determine the safe yield for any new pumping that might occur within the property boundary of the 4-S Ranch. Further exploitation of the groundwater will be limited if the leakage from the Eastside Bypass, Mariposa Bypass and Bear Creek are insufficient to replace the pumped water on an average annual basis.

Other factors for consideration are that the existing wells were likely installed in 1960's or 1970's and are at least 30 years old. Also, several of the wells were observed to be producing sand. August Oertzen mentioned that sand was being added through the casing access tube to replace the sand being removed from the pump bowl. This sand causes wear to pump parts. It is possible that several of the production wells would need to be replaced if maximum well field yield was to be sustained.

\section{REFERENCES}

California Department of Water Resources. 2003. Bulletin 118: California's Groundwater, Update 2003, April 2003.

Bookman-Edmonston, 2003. Hydrogeologic Assessment. Prepared for Stevinson Water District. December 2003. 30p.

GEI Consultants, 2004. Water Supply, Water Recycling and Storm Water management Evaluation. Prepared for Stevinson Ranch Development. 58p. 
Oertzen August. 2005. Personal communication related to 4-S Ranch operations, groundwater development history and water resources. 4-S Ranch, Merced, CA.

Schmidt K.D. 2005. Kenneth D. Schmidt and Associates. Groundwater Conditions in the Stevinson Area. Prepared for Bates Properties, Inc., Monterey, California. August 2005. 46 p + appendices.

U.S. Geological Survey. 1971a. Data for Wells in the Modesto-Merced Area San Joaquin Valley, California. Prepared in cooperation with the California Department of Water Resources. Open-File Report. Menlo Park, California.

U.S. Geological Survey. 1971b. Geology, Hydrology, and Water Quality of the Tracy-Dos Palos Area, San Joaquin Valley, California. Prepared in cooperation with the California Department of Water Resources. Open-File Report. Menlo Park, California.

U.S. Geological Survey. 1973. Base of Fresh Ground Water (Approximately 3,000 Micromhos) in the San Joaquin Valley, California. Hydrologic Investigations, Atlas HA-489. Prepared in cooperation with the California Department of Water Resources. Washington D.C.

U.S. Geological Survey. 1986. Geology of the Fresh Ground-Water Basin of the Central Valley, California, with Texture Maps and Sections: Regional Aquifer-System Analysis. U.S. Geological Survey Professional Paper 1401-C.

US Geological Survey. 1983. Groundwater Conditions and Shallow test-Well Information in the Eastern Half of Merced County, California, 1977-82. Prepared in Cooperation with the City of Merced. Water Resources Investigations, report 83-4081.

U.S. Geological Survey. 1989. Ground-Water Flow in the Central Valley, California: Regional AquiferSystem Analysis. U.S. Geological Survey Professional Paper 140 1-D

U.S. Geological Survey. 1989. Study and Interpretation of the Chemical Characteristics of Natural Water, Third Edition. U.S. Geological Survey Water-Supply Paper 2254.

U.S. Geological Survey. 1991. Ground Water in the Central Valley, California-A Summary Report: Regional Aquifer-System Analysis. U.S. Geological Survey Professional Paper 1401 -A. 


\section{APPENDIX A. PUMP TESTS CONDUCTED BY ANDERSON PUMP COMPANY IN OCTOBER 2004}

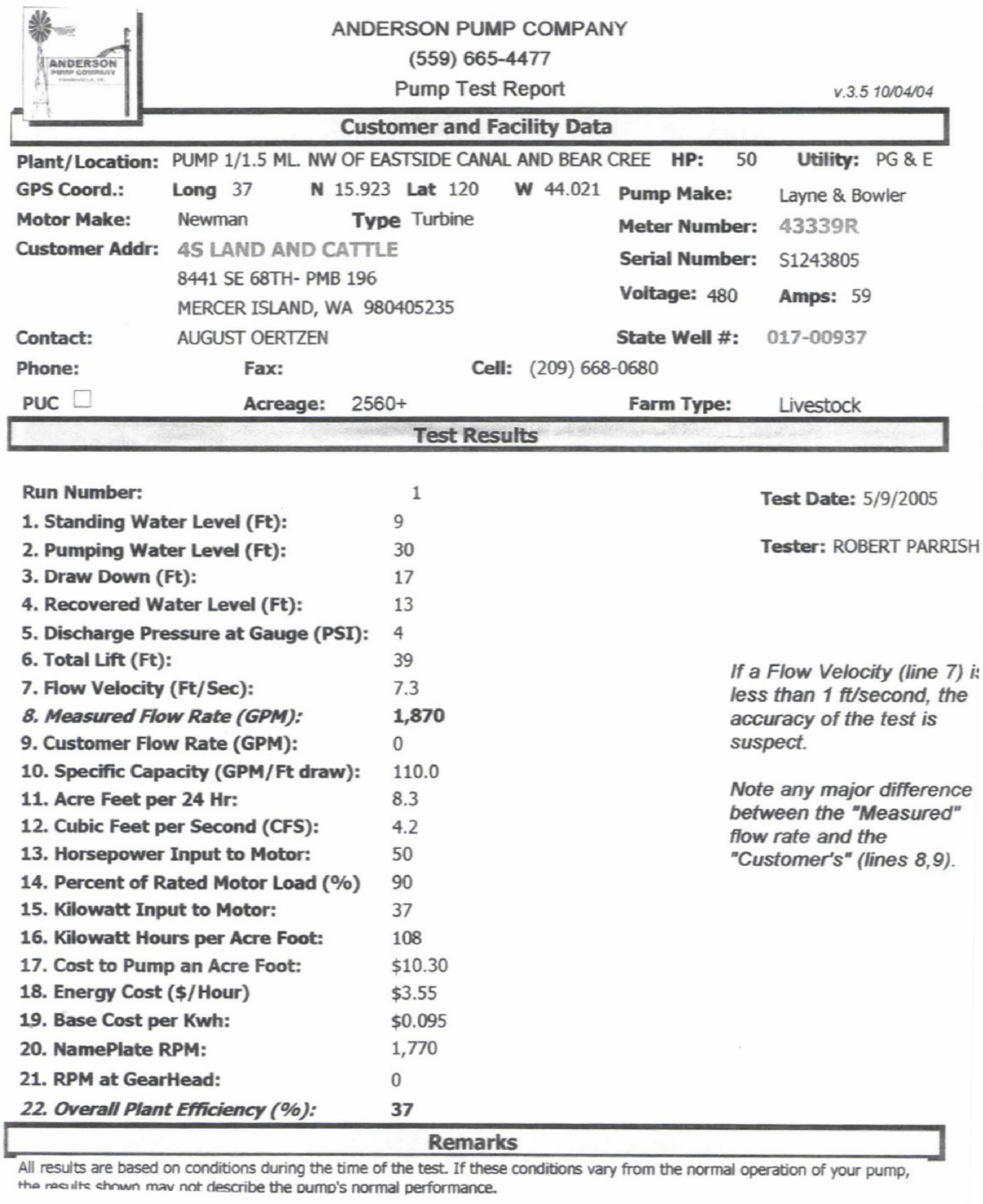




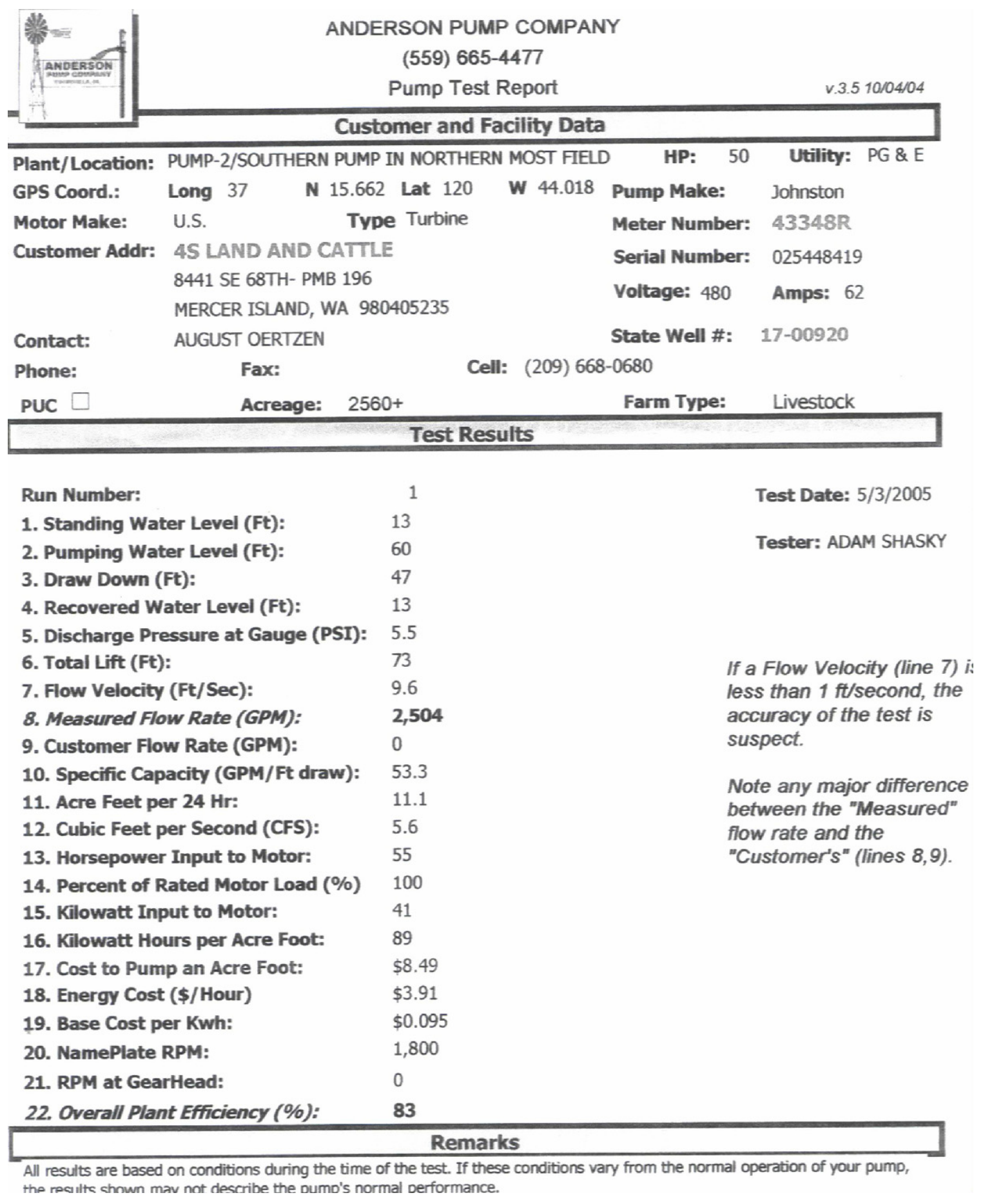




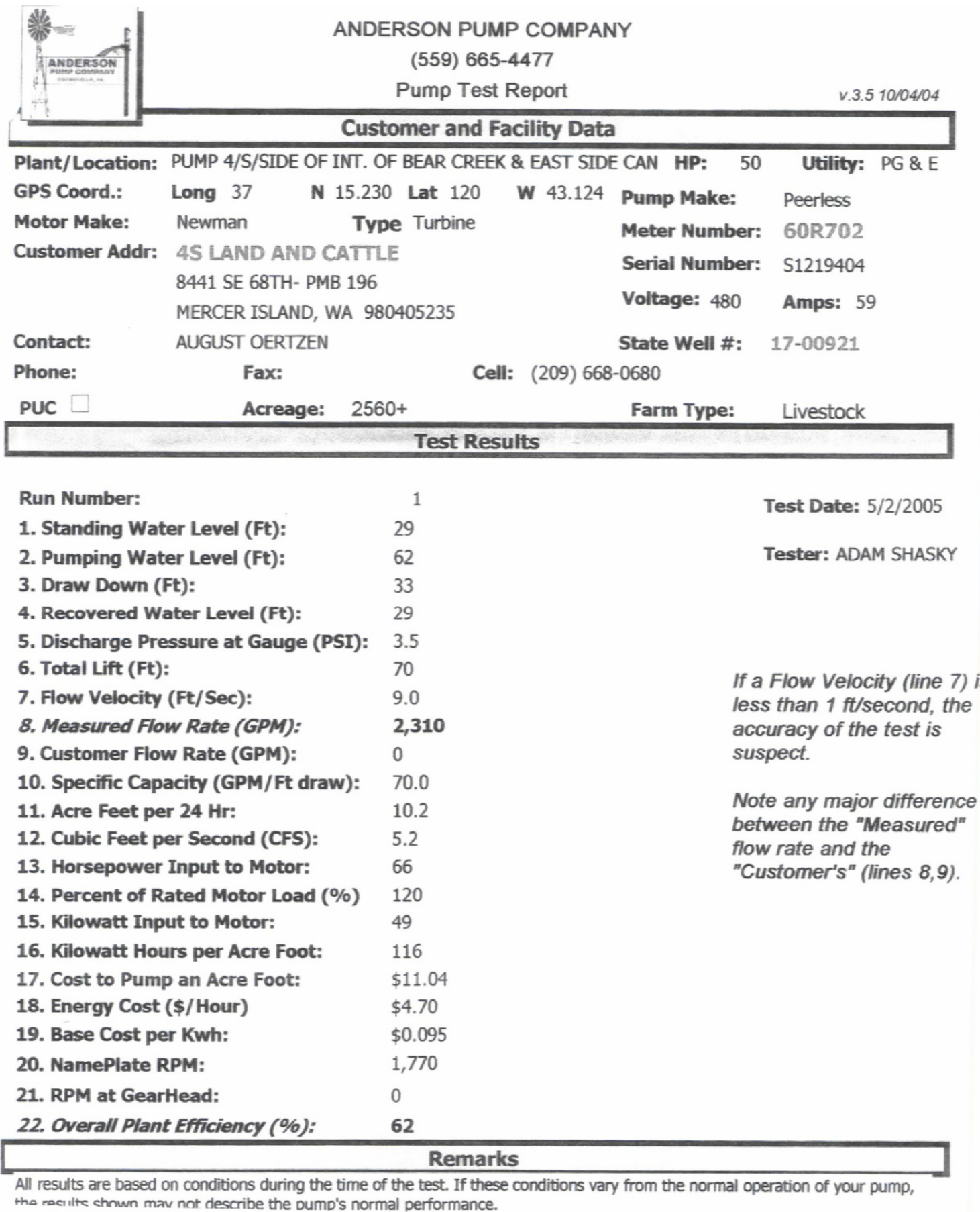




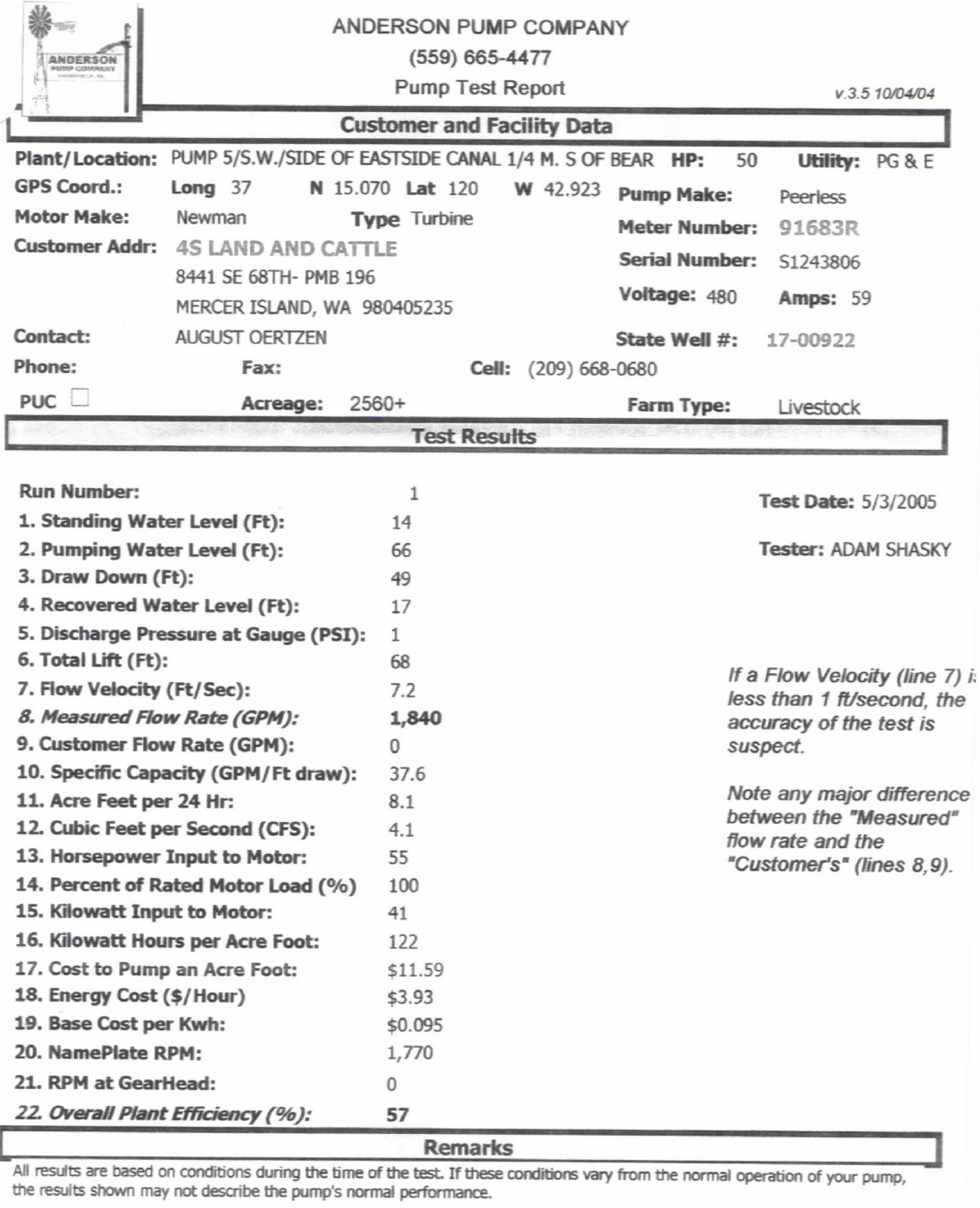




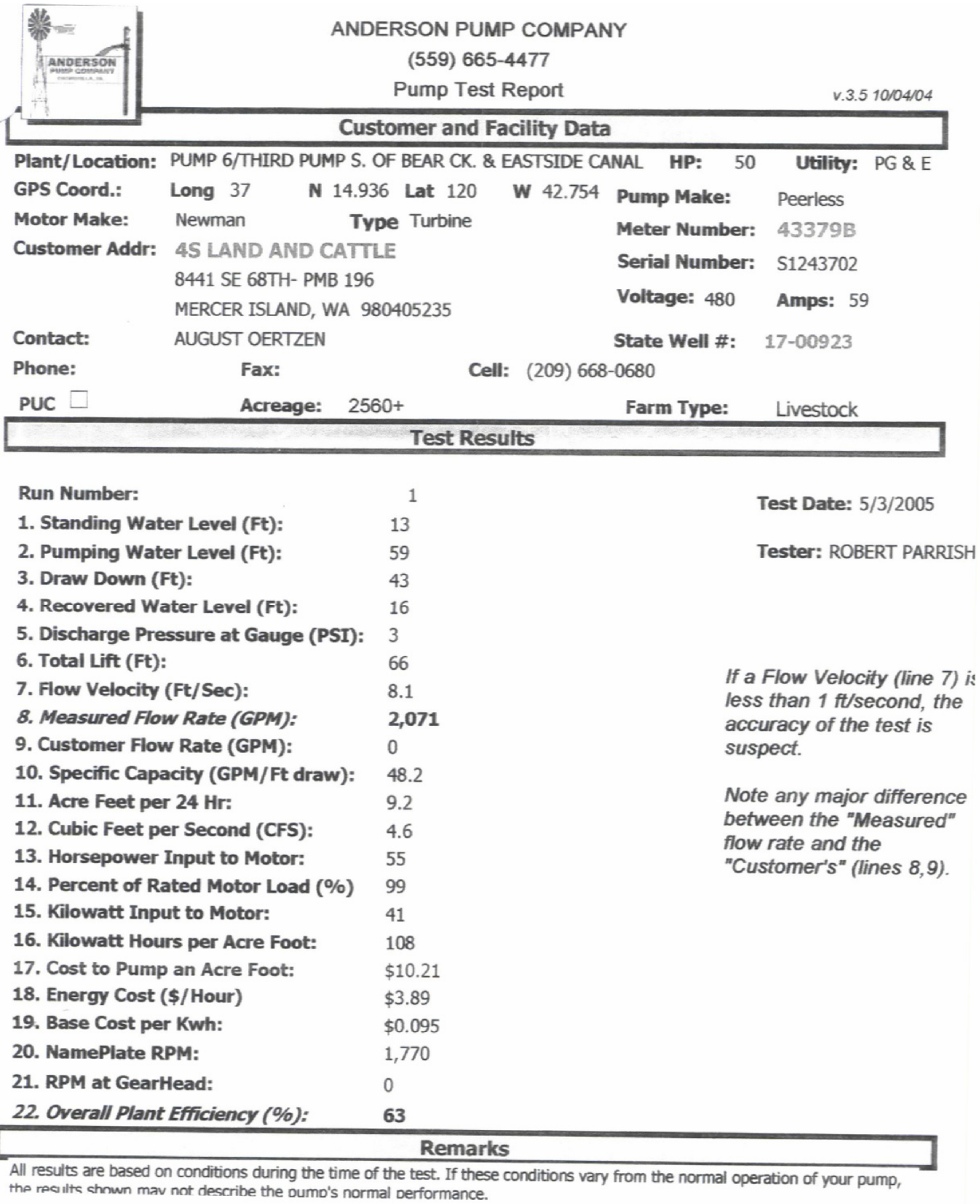




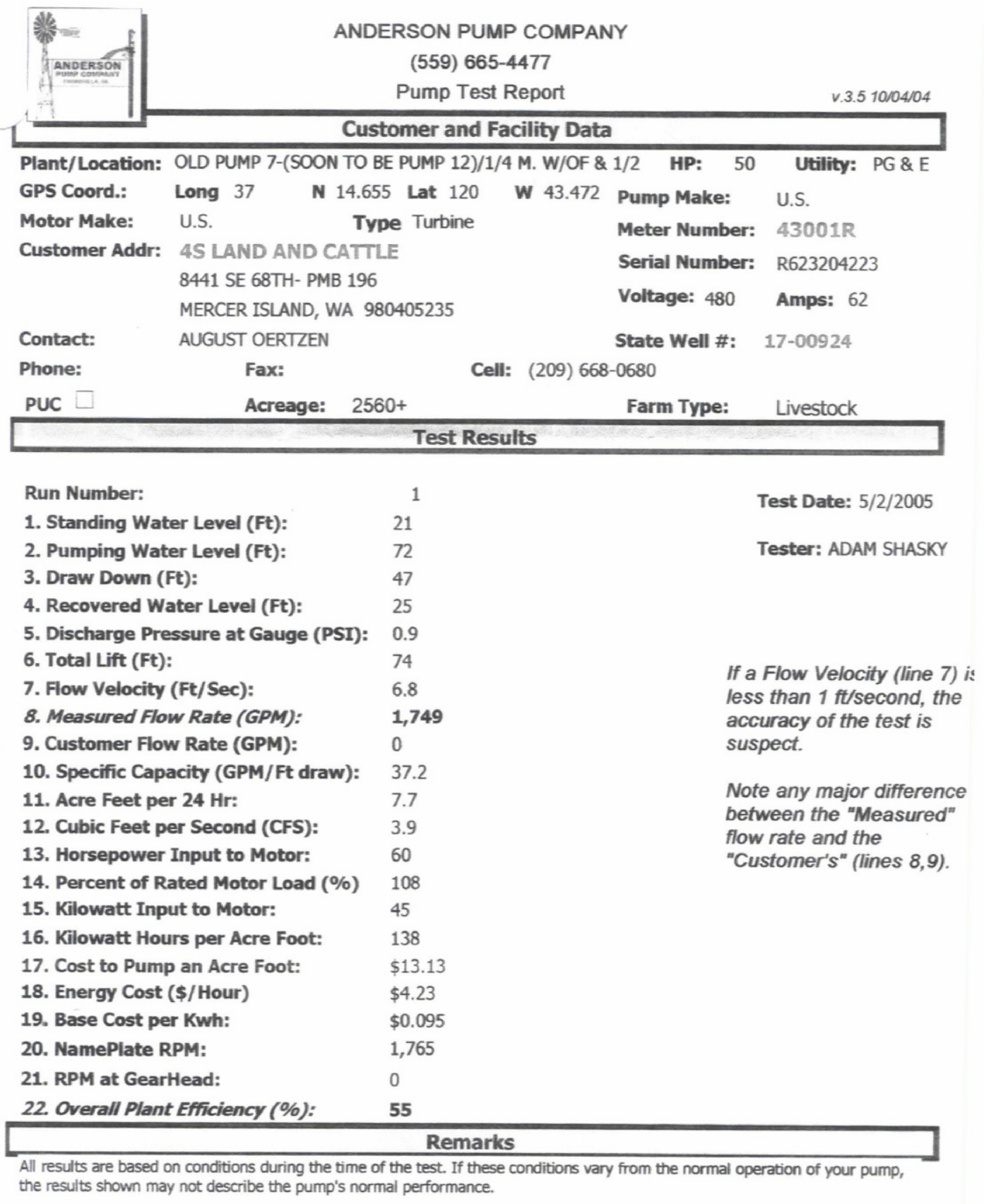




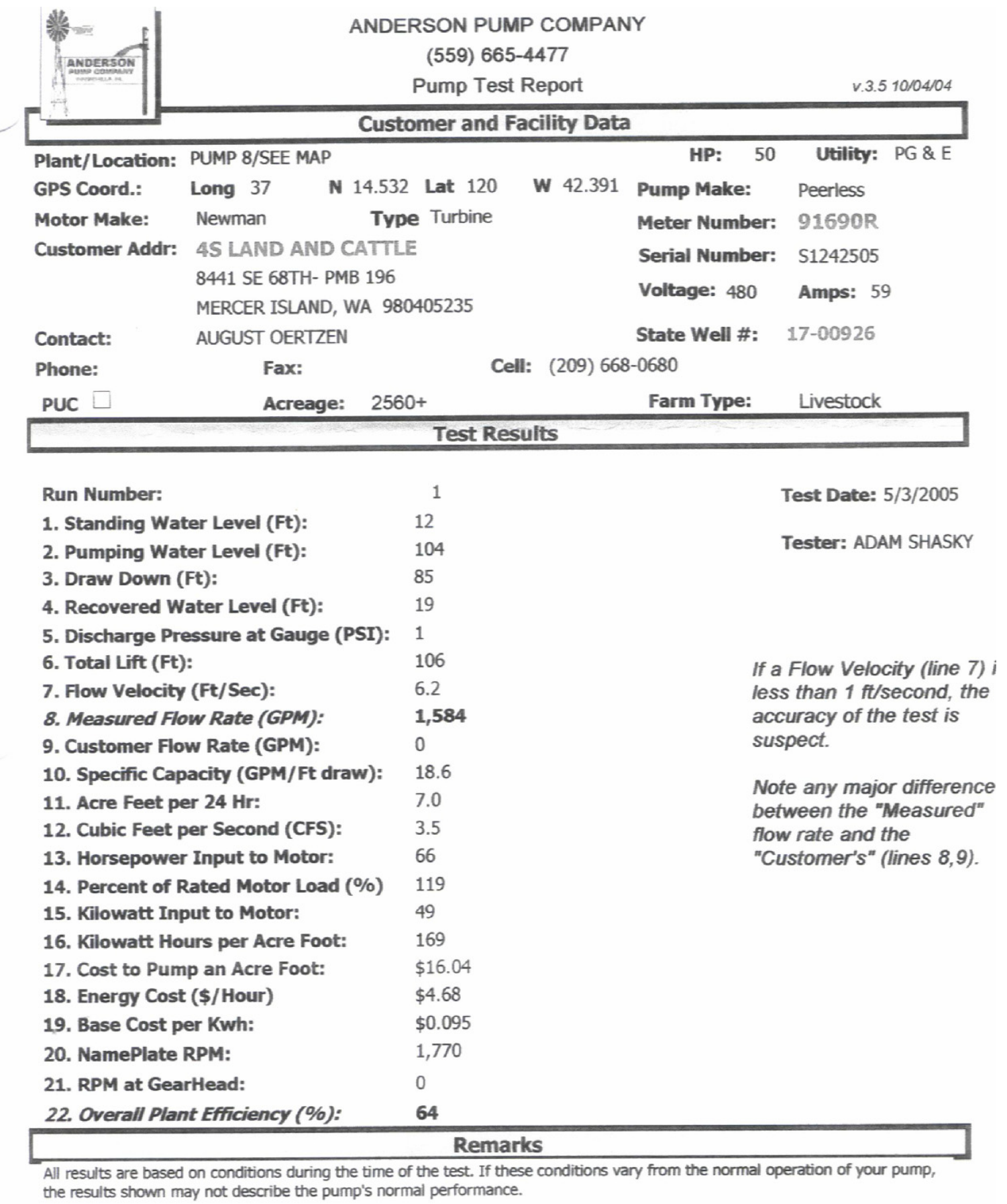




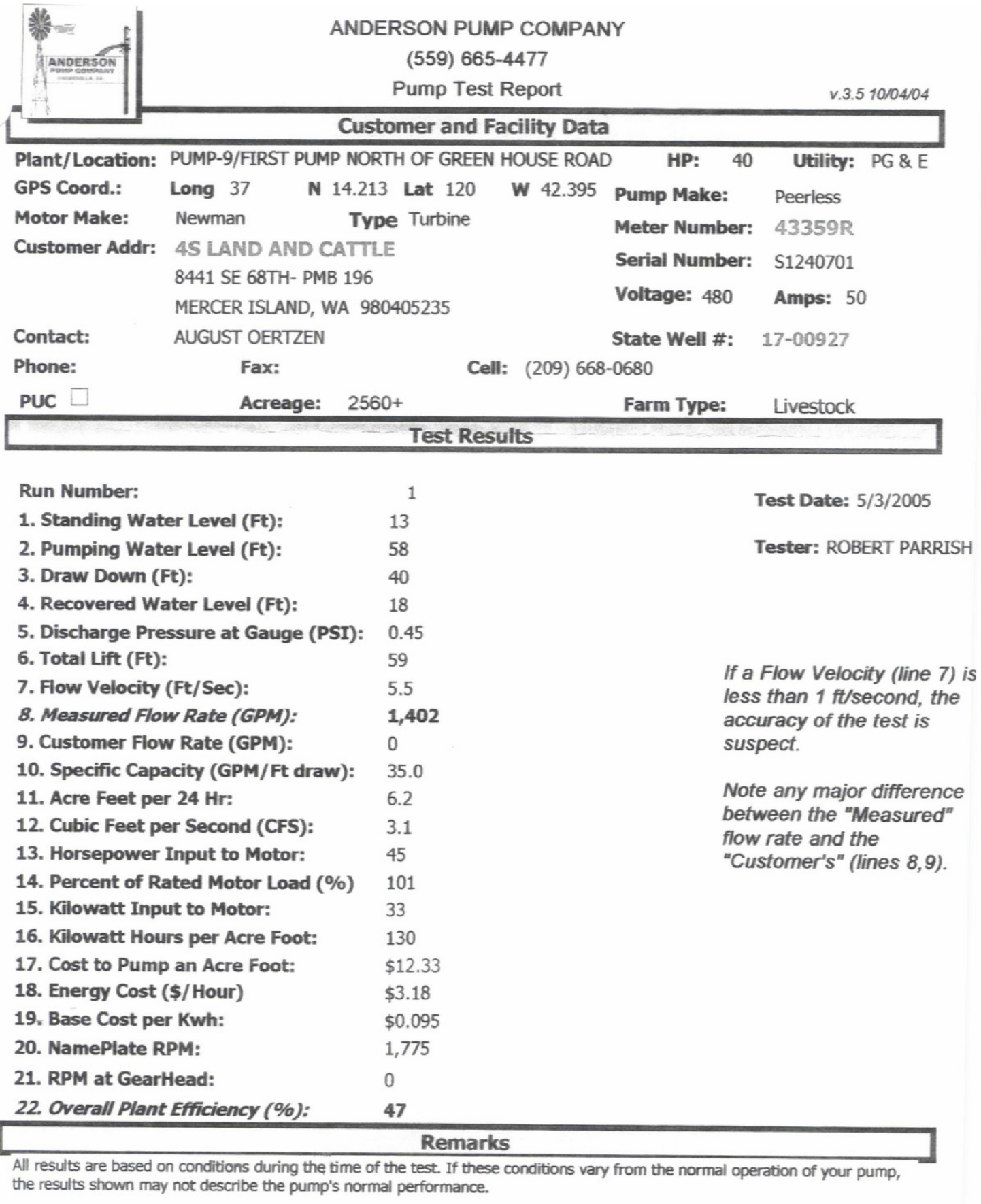


Pump Test Kepon

Customer and Facility Data

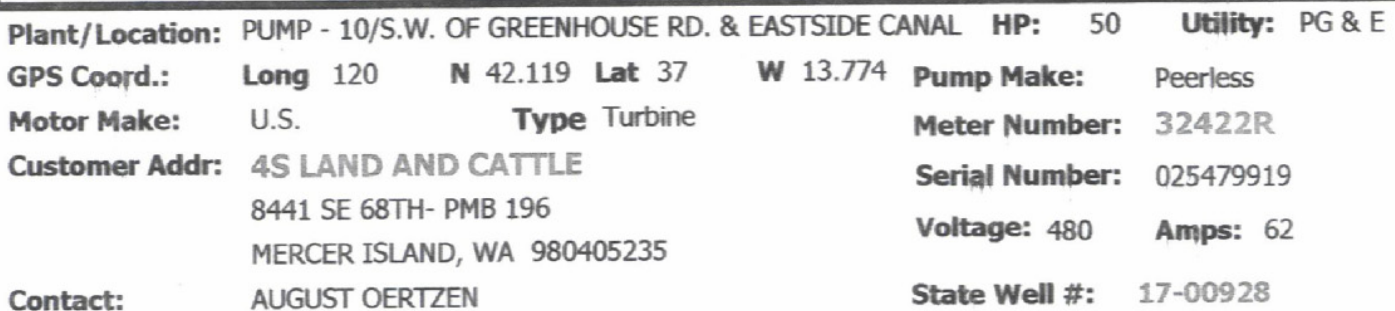

Phone:

Fax:

Cell: (209) $668-0680$

PuC $\square$ Acreage: 2560+ $\quad$ Farm Type: Livestock

Run Number:

1. Standing Water Level (Ft): $\quad 14.2$

2. Pumping Water Level (Ft): $\quad 40.2$

3. Draw Down (Ft): 22

4. Recovered Water Level (Ft): $\quad 18.2$

5. Discharge Pressure at Gauge (PSI): 0.9

6. Total Lift (Ft): $\quad 42$

7. Flow Velocity (Ft/Sec): $\quad 9.1$

8. Measured Flow Rate (GPM): 2,343

9. Customer Flow Rate (GPM): 0

10. Specific Capacity (GPM/Ft draw): $\quad 106.5$

11. Acre Feet per $24 \mathrm{Hr}: \quad 10.4$

12. Cubic Feet per Second (CFS): $\quad 5.2$

13. Horsepower Input to Motor: 51

14. Percent of Rated Motor Load (\%) 92

15. Kilowatt Input to Motor: 38

16. Kilowatt Hours per Acre Foot: $\quad 88$

17. Cost to Pump an Acre Foot: $\$ \$ 8.34$

18. Energy Cost (\$/Hour) $\$ 3.60$

19. Base Cost per Kwh: $\$ \$ 0.095$

20. NamePlate RPM: $\quad 1,800$

21. RPM at GearHead: $\quad 0$

22. Overall Plant Efficiency (\%): $\quad 49$
Test Date: 5/3/2005

Tester: ROBERT PARRISI

If a Flow Velocity (line 7) less than $1 \mathrm{ft} / \mathrm{second}$, the accuracy of the test is suspect.

Note any major difference between the "Measured" flow rate and the "Customer's" (lines 8,9).

All results are based on conditions during the time of the test. If these conditions vary from the normal operation of your pump, the results shown may not describe the pump's normal performance. 


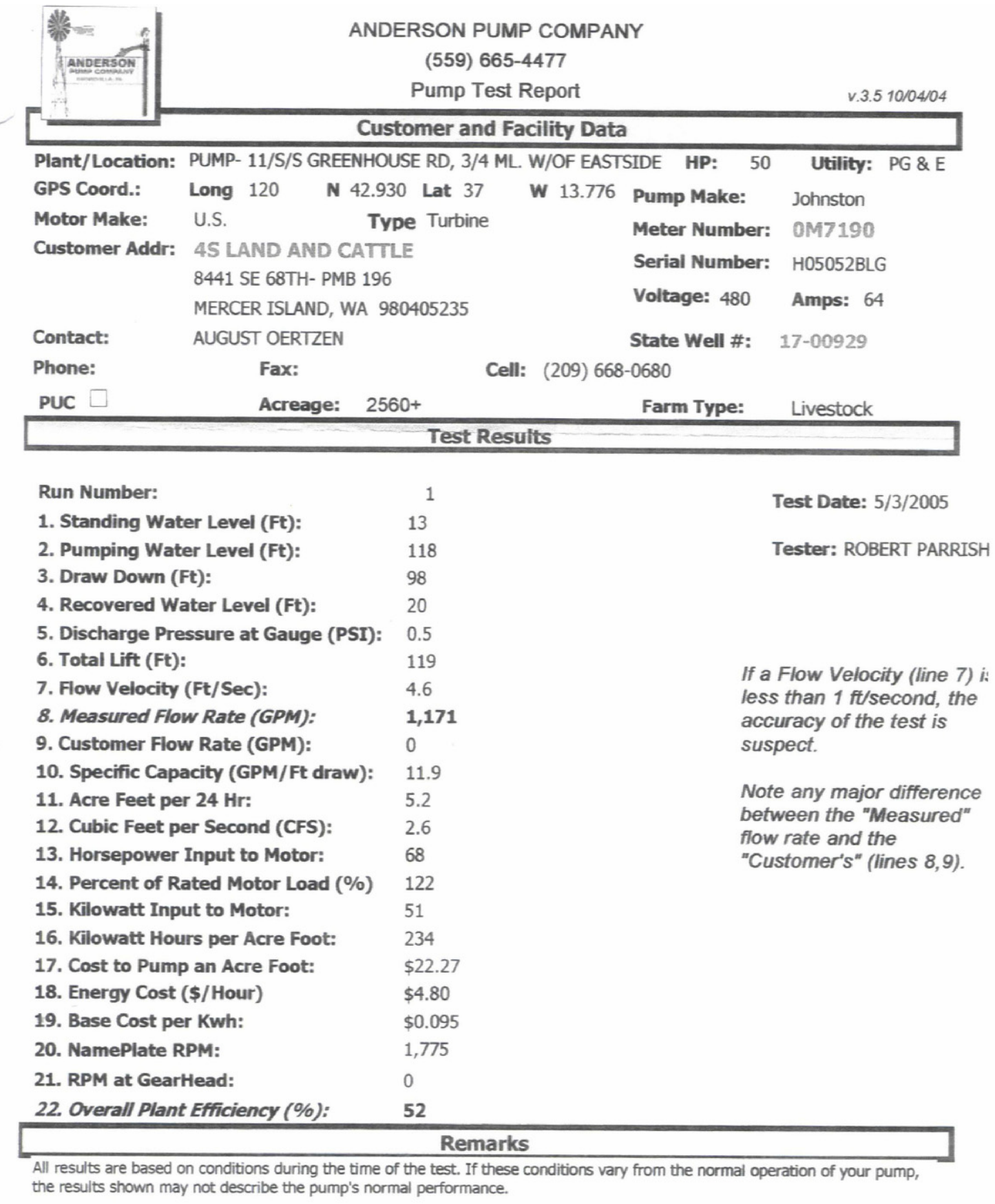

